Provided for non-commercial research and education use. Not for reproduction, distribution or commercial use.

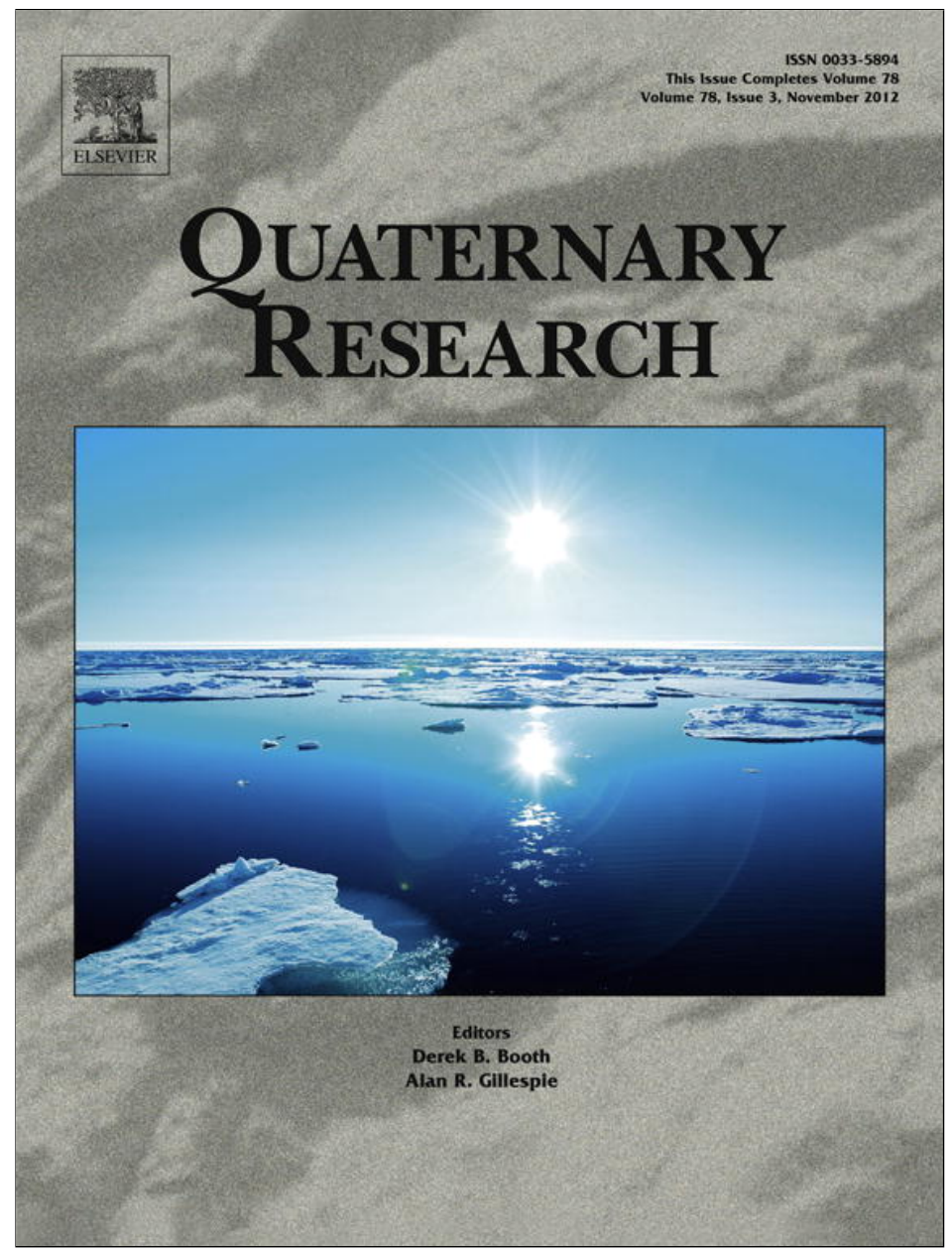

This article appeared in a journal published by Elsevier. The attached copy is furnished to the author for internal non-commercial research and education use, including for instruction at the authors institution and sharing with colleagues.

Other uses, including reproduction and distribution, or selling or licensing copies, or posting to personal, institutional or third party websites are prohibited.

In most cases authors are permitted to post their version of the article (e.g. in Word or Tex form) to their personal website or institutional repository. Authors requiring further information regarding Elsevier's archiving and manuscript policies are encouraged to visit:

http://www.elsevier.com/copyright 


\title{
Late glacial and Holocene sedimentation, vegetation, and climate history from easternmost Beringia (northern Yukon Territory, Canada)
}

\author{
Michael Fritz ${ }^{\mathrm{a}, *}$, Ulrike Herzschuh ${ }^{\mathrm{a}, \mathrm{b}}$, Sebastian Wetterich ${ }^{\mathrm{a}}$, Hugues Lantuit ${ }^{\mathrm{a}}$, Gregory P. De Pascale ${ }^{\mathrm{c}}$, \\ Wayne H. Pollard ${ }^{\mathrm{d}}$, Lutz Schirrmeister ${ }^{\mathrm{a}}$ \\ a Alfred Wegener Institute for Polar and Marine Research, Department of Periglacial Research, Telegrafenberg A43, 14473 Potsdam, Germany \\ ${ }^{\mathrm{b}}$ Potsdam University, Institute of Earth and Environmental Sciences, Karl-Liebknecht-Str. 24-25, 14476 Potsdam-Golm, Germany \\ c University of Canterbury, Department of Geological Sciences, Private Bag 4800, Christchurch 8140, New Zealand \\ ${ }^{\mathrm{d}}$ McGill University, Department of Geography, 805 Sherbrooke St. West, H3A2K6 Montreal, Ouebec, Canada
}

\section{A R T I C L E I N F O}

\section{Article history:}

Received 5 August 2011

Available online 11 August 2012

\section{Keywords:}

Trout Lake

Laurentide Ice Sheet

Younger Dryas

Holocene thermal maximum

Lake sediments

Pollen

Temperature reconstruction

Precipitation reconstruction

WAPLS

Modern analogue technique

\begin{abstract}
A B S T R A C T
Beringian climate and environmental history are poorly characterized at its easternmost edge. Lake sediments from the northern Yukon Territory have recorded sedimentation, vegetation, summer temperature and precipitation changes since $\sim 16$ cal ka BP. Herb-dominated tundra persisted until $\sim 14.7$ cal ka BP with mean July air temperatures $\leq 5^{\circ} \mathrm{C}$ colder and annual precipitation 50 to $120 \mathrm{~mm}$ lower than today. Temperatures rapidly increased during the Bølling/Allerød interstadial towards modern conditions, favoring establishment of Betula-Salix shrub tundra. Pollen-inferred temperature reconstructions recorded a pronounced Younger Dryas stadial in east Beringia with a temperature drop of $\sim 1.5^{\circ} \mathrm{C}\left(\sim 2.5\right.$ to $3.0^{\circ} \mathrm{C}$ below modern conditions) and low net precipitation (90 to $170 \mathrm{~mm}$ ) but show little evidence of an early Holocene thermal maximum in the pollen record. Sustained low net precipitation and increased evaporation during early Holocene warming suggest a moisture-limited spread of vegetation and an obscured summer temperature maximum. Northern Yukon Holocene moisture availability increased in response to a retreating Laurentide Ice Sheet, postglacial sea level rise, and decreasing summer insolation that in turn led to establishment of Alnus-Betula shrub tundra from $\sim 5$ cal ka BP until present, and conversion of a continental climate into a coastal-maritime climate near the Beaufort Sea.
\end{abstract}

(c) 2012 University of Washington. Published by Elsevier Inc. All rights reserved.

\section{Introduction}

During the late Wisconsin glacial episode (28-10 cal ka BP), the Bering land bridge connected the unglaciated parts of Alaska and the Yukon Territory with eastern Siberia to form an extensive continuous landmass known as Beringia (Hopkins, 1982). Beringian environments are of particular interest because they served as glacial refugia for various taxa (Hultén, 1937; Guthrie, 2001) and enabled the migration of plants, animals, and early humans between Eurasia and North America (Morlan and Cinq-Mars, 1982; Mason et al., 2001). The northern Yukon was the easternmost boundary of Beringia and in close vicinity to the Laurentide Ice Sheet (LIS). It has undergone distinct changes in climate, landscape, and ecology after the late glacialHolocene transition that includes the latest part of the full glacial, the late glacial warming known as the Bølling/Allerød (B/A) interstadial, the Younger Dryas (YD) stadial, and the early Holocene thermal maximum (HTM). Paleoenvironmental evidence for the YD is found in

\footnotetext{
* Corresponding author. Fax: +49331288 2188.

E-mail address: Michael.Fritz@awi.de (M. Fritz).
}

terrestrial and lake sediment records (e.g., Elias, 2000; Brubaker et al., 2001; Briner et al., 2002; Hu et al., 2002; Yu et al., 2008) as well as in ground ice from Alaska (Meyer et al., 2010). However, the regional paleoclimate dynamics during the late glacial-Holocene transition and the YD in general-and in east Beringia in particular-are still not completely understood (Hu et al., 2006; Viau et al., 2008).

Although a number of paleoenvironmental investigations have been undertaken in eastern Beringia, hitherto only one lake sediment record has been available from the northern Yukon that provides a continuous record of vegetation change (Hanging Lake; Cwynar, 1982). The Hanging Lake record was thought to cover a time period from $\sim 33{ }^{14} \mathrm{C}$ ka BP to the present (Cwynar, 1982). However, this lake record was recently revised to infer a maximum-limiting age of $\sim 17$ cal ka BP (Kurek et al., 2009).

Even though there is a general consensus that unglaciated late glacial landscapes were a heterogeneous mosaic of vegetation communities (Kurek et al., 2009), little is known about vegetation and temperature dynamics northwest of the collapsing LIS close to the Arctic Ocean. Several studies have focused on biological proxies such as pollen, chironomids, and ostracods to reconstruct air temperatures (Bunbury and Gajewski, 2009; Kurek et al., 2009), vegetation history (e.g., Rampton, 
1971; Cwynar, 1982; Ritchie, 1984; Cwynar and Spear, 1995; Lacourse and Gajewski, 2000; Vermaire and Cwynar, 2010), and changes in available moisture and lake level (Pienitz et al., 2000; Kurek et al., 2009). However, only a few studies have investigated the late Pleistocene and Holocene sedimentation history or have taken into account lake-basin evolution and limnogeological succession (Engstrom et al., 2000). Nevertheless, such studies are important because the development of lakes in easternmost Beringia in close vicinity to the former LIS margin is still understudied, though such lakes often contain continuous paleoenvironmental archives.

The aim of this study was, therefore, to gain a comprehensive understanding of the timing of landscape and environmental changes in the unglaciated northern Yukon since the late Wisconsin using lake sediments from Trout Lake to address the following specific questions:

1. How did lake sedimentation respond to the late glacial-Holocene climate transition in close vicinity to the collapsing LIS?

2. What were the mean July air temperatures in ice-marginal eastern Beringia since the late glacial-Holocene transition?

3. Was there a pronounced YD stadial in east Beringia far apart from an Atlantic and Pacific influence, and if so, what were the climatic magnitudes?

4. How did pollen-inferred moisture patterns correspond to LIS retreat, postglacial sea-level rise and Holocene warming?

\section{Study site and regional setting}

Trout Lake $\left(68^{\circ} 49.73^{\prime} \mathrm{N}, 138^{\circ} 44.78^{\prime} \mathrm{W}\right)$ is located $163 \mathrm{~m}$ above sea level in the foothills of the British Mountains, approximately $1 \mathrm{~km}$ west of the Babbage River and about $42 \mathrm{~km}$ south of the Beaufort Sea (Fig. 1a). The lake has a measured maximum water depth of $10.2 \mathrm{~m}$ and is roughly rectangular with an area of $0.84 \mathrm{~km}^{2}$. The catchment is small; steep bedrock slopes rise from the lake in the south and east, while a gently rolling plateau is situated to the north and west of the lake where a small outlet stream and three smaller lakes are found (Fig. 1b). Trout Lake is about $40 \mathrm{~km}$ north of the modern tree line (Welsh and Rigby, 1971) within the zone of continuous permafrost. The surrounding bedrock is dominated by Jurassic to Lower Cretaceous shale and siltstone (Norris, 1977). The northern British Mountains have extensive pediments of gentle gradient (French and Harry, 1992) towards the Yukon Coastal Plain (YCP) to the north. The study area lies beyond the maximum limit of Pleistocene glaciations (Fig. 1); Hughes (1972) and Rampton (1982) have pointed out that the last major ice advance (Buckland glaciation of Wisconsin age) was restricted to the YCP to the north and northeast of Trout Lake.

The modern climate of the northernmost part of the Yukon is subarctic maritime in summer during the open-water season of the southern Beaufort Sea, and continental in winter with pronounced anticyclonic influence (Wahl et al., 1987). The mean annual air temperature (1971-2000) is $-9.9^{\circ} \mathrm{C}$ at Shingle Point, the closest weather station
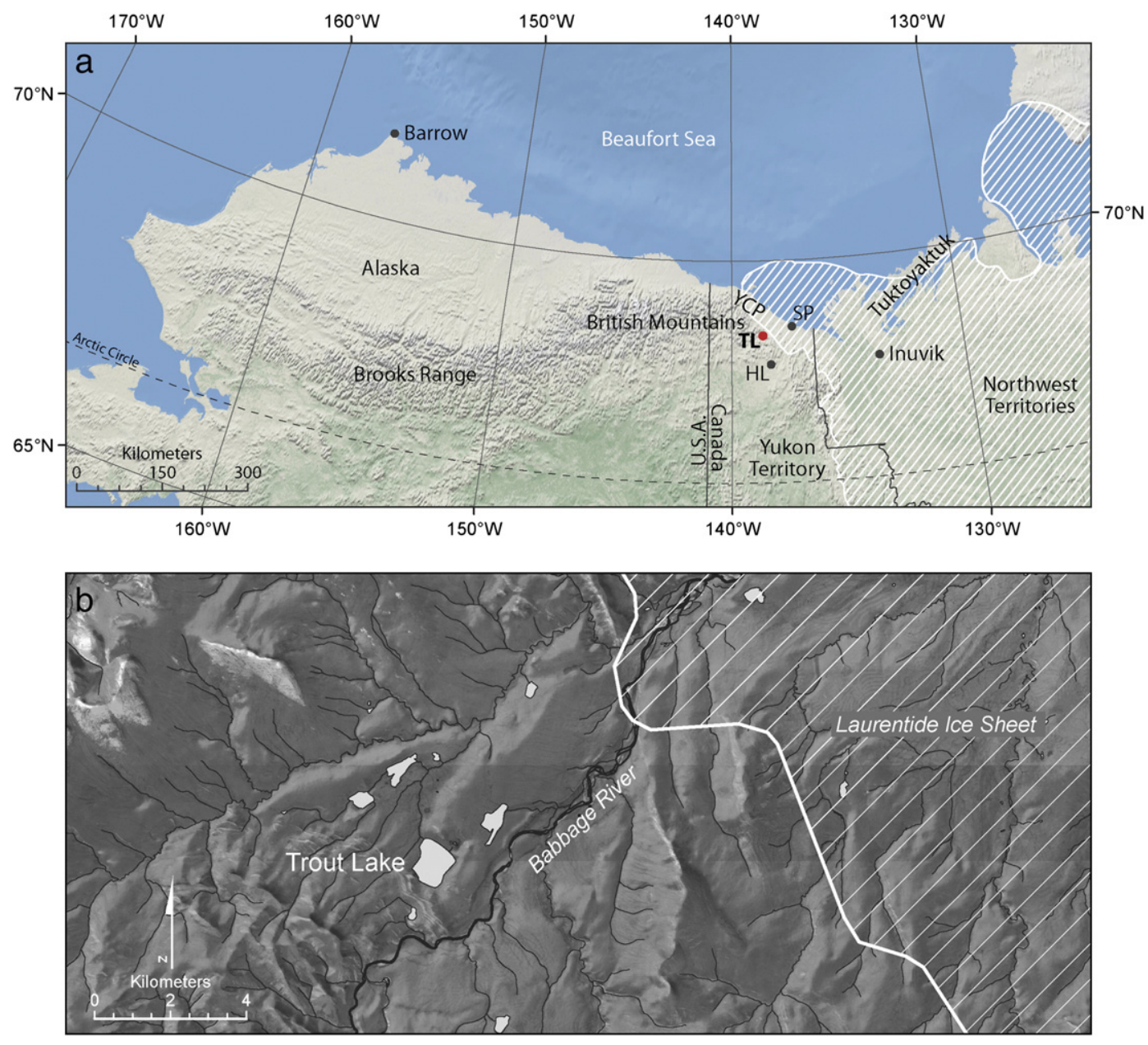

Figure 1. (a) Location map of the western Arctic. Striated area indicates last glacial maximum (LGM) Laurentide ice limit after Dyke and Prest (1987); TL-Trout Lake, HL-Hanging Lake, SP-Shingle Point, YCP-Yukon Coastal Plain. (b) Trout Lake study site $\left(68^{\circ} 49.73^{\prime} \mathrm{N}, 138^{\circ} 44.78^{\prime} \mathrm{W}\right)$ and surrounding area with local drainage and hydrology. Trout Lake is shown in close-up in Fig. 2. The background map is based on a Rapideye satellite image (red band, stretched and displayed in grayscale, $5 \mathrm{~m}$ resolution) overlain with the Yukon Digital Elevation Model (30 m resolution). 
$\sim 50 \mathrm{~km}$ northeast of Trout Lake, with an average July maximum of $11.2^{\circ} \mathrm{C}$ (Environment Canada, 2000). Mean annual precipitation is $254 \mathrm{~mm} / \mathrm{yr}$ and is almost equally shared between rain and snow (Environment Canada, 2000). The modern catchment vegetation is dominated by heath tundra and fellfield communities, including boreal taxa such as Alnus crispa, Betula glandulosa and Salix, and herbs such as Empetrum nigrum, Vaccinium uliginosum, Vaccinium vitis-idaea, Arctous alpina and Anemone sp. (Welsh and Rigby, 1971; Kienast, F., personal communication, 2011).

\section{Material and methods}

Coring and on-site sampling

The selection of the coring site was based on bathymetric profiling and ground penetrating radar (GPR) surveys carried out in August 2008 and April 2009, respectively. Bathymetric profiling was undertaken via boat in August and through drill holes in the lake ice in April. A MALÅ GPR system with both $50 \mathrm{MHz}$ and $100 \mathrm{MHz}$ unshielded rough-terrain

a

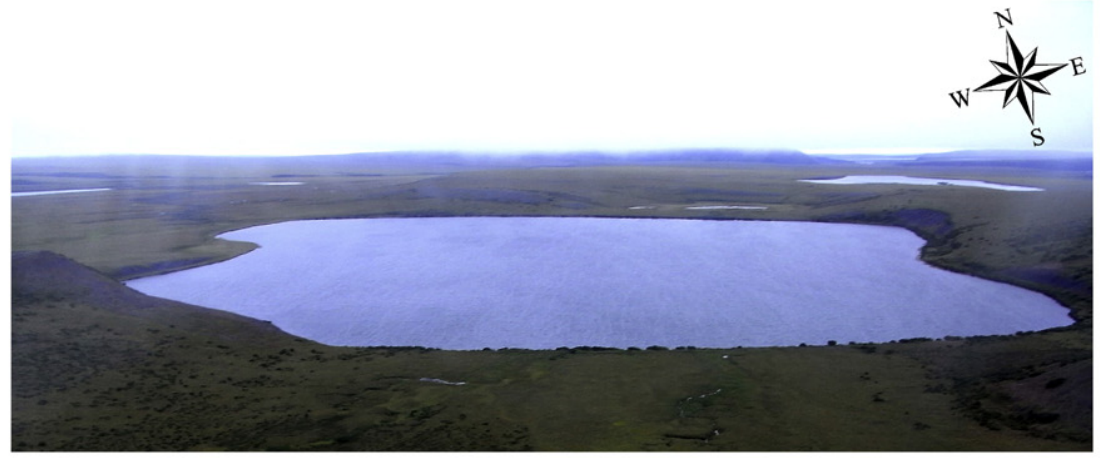

b
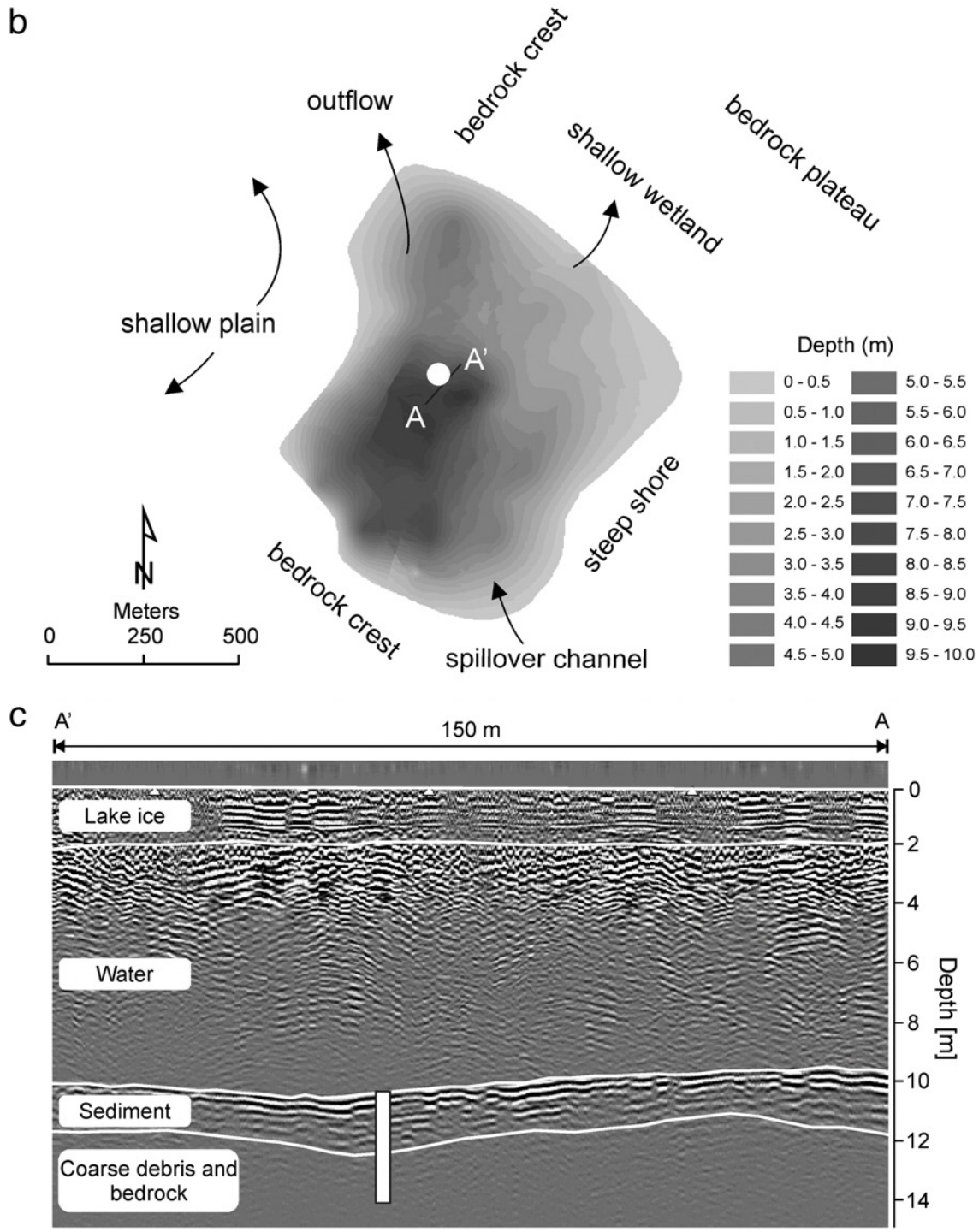

Figure 2. (a) Photograph showing the modern lake. (b) Trout Lake bathymetry and coring location (white circle) from April 2009. The bathymetry map is based on the ArcGIS TOPOGRID module using a combination of different datasets including echosounding from boat surveys in summer, conventional depth sounding from holes drilled in the lake ice in winter, and depths derived from ground penetrating radar (GPR) profiles collected on the lake ice in winter. (c) Interpreted GPR profile (100 MHz) across the coring location (white bar). 
antennas (RTA) was used on the frozen lake surface to map the lake bathymetry, lake-bed sediments (Fig. 2), and surrounding stratigraphy of Trout Lake during April 2009. GPR data were processed with REFLEXW software using direct-coupling wave horizontal filtering to remove noise. These results were used to locate a coring site with the thickest sediment sequence. A $405 \mathrm{~cm}$-long sediment core was retrieved from the deepest part of the lake at a water depth of $8.70 \mathrm{~m}$. Coring was carried out from a tripod mounted on the 2-m-thick lake ice using a UWITEC piston corer. Bedrock at the base of the sediments prevented further penetration of the corer. Upon recovery, the overlapping sediment cores were cut into segments up to $100 \mathrm{~cm}$ in length, which were stored cool (but above freezing) in dark conditions. In the laboratory sediment cores were split in half, photographed, and described, and $1-\mathrm{cm}$ slices were sampled at $5-\mathrm{cm}$ intervals for further analyses. For description of the recent limnology, surface and bottom-water samples were taken during both field seasons for determination of stable water isotopes $\left(\delta^{18} \mathrm{O}, \delta \mathrm{D}\right)$, electrical conductivity, $\mathrm{pH}, \mathrm{O}_{2}$, and the major anion and cation composition.

\section{Geochronology}

Core samples were wet-sieved ( $>250 \mu \mathrm{m})$ to isolate plant macrofossils, which were then cleaned and hand-picked for AMS (accelerator mass spectrometry) radiocarbon dating at the Poznan Radiocarbon Laboratory (Adam Mickiewicz University, Poznan, Poland). Six radiocarbon ages obtained by AMS dating on predominantly terrestrial moss remains are the basis of the core chronology (Table 1). Ages were calibrated using "CALIB 6.0" (Stuiver and Reimer, 1993; Data set: IntCal09: Reimer et al., 2009) and are denoted as calibrated thousand years before present ( $\mathrm{cal} \mathrm{ka} \mathrm{BP).} \mathrm{We} \mathrm{report} \mathrm{the} \mathrm{median} \mathrm{of} \mathrm{the} \mathrm{2-sigma} \mathrm{probability}$ distribution.

\section{Sediment properties}

The magnetic susceptibility (MS, $10^{-5}$ SI units) was measured for facies change detection on the halved core with a multi-sensor core logger (MSCL, GEOTEK) at 1-cm increments and is displayed using a 5 -point running average. Core lithology was determined by detailed manual core logging including descriptions of sediment texture and structures, color, and biogenic features. The laboratory measurements and detailed core descriptions were used to characterize sediment units and transitions.

Freeze-drying of the samples yielded estimates of water content. A laser particle analyzer (Coulter LS 200) was used for grain-size analyses on organic-free (treated with $30 \% \mathrm{H}_{2} \mathrm{O}_{2}$ ) subsamples of the $<2$-mm fraction. Sodium pyrophosphate (decahydrate) was used as dispersant. The remaining particles greater than $2 \mathrm{~mm}$ were reintegrated into the grain-size statistics using the SediVision 2.0 software. Total carbon (TC), total organic carbon (TOC), total nitrogen (TN), and total sulfur (TS) contents were measured with a carbon-nitrogen-sulfur (CNS) analyzer (Elementar Vario EL III), and are given as weight percent (wt.\%). The $\mathrm{C} / \mathrm{N}$ ratio (C/S ratio) is expressed as the quotient of TOC and TN (TS) values. Stable carbon isotope ratios $\left(\delta^{13} \mathrm{C}\right)$ of TOC were measured on carbonate-free (treated with $10 \% \mathrm{HCl}$ ) samples with a combination of a mass spectrometer (DELTAplusXL, Finnigan) and an elemental analyzer (Carlo-Erba CN2500) at the German Research Centre of Geosciences (GFZ) in Potsdam, Germany. The values are expressed in delta per mil notation $(\delta, \%$ ) relative to the Vienna Pee Dee Belemnite (VPDB) standard.

\section{Pollen treatment and numerical methods}

Preparation of the pollen samples included treatment with $\mathrm{HCl}$, $\mathrm{KOH}, \mathrm{HF}$, acetolysis, sieving, and mounting in glycerin (Faegri and Iversen, 1989). Two tablets of Lycopodium spores were added to calculate the pollen concentration. The sediment core was analyzed at 27 intervals in which at least 300 terrestrial pollen grains (excluding spores and aquatic taxa) were counted at each level. In the basal core sample, where pollen concentration was very low (2290 grains $\left./ \mathrm{cm}^{3}\right)$, 182 grains were counted. Pollen identifications were based on the relevant literature (McAndrews et al., 1973; Moore et al., 1991; Beug, 2004). Pollen percentages were square-root transformed prior to all statistical analyses, and only pollen taxa that were present with an abundance of $\geq 0.5 \%$ in at least three samples were included in further analyses.

The definition of local pollen zone (PZ) boundaries within the pollen percentage diagram was based on a Constrained Incremental Sum of Squares cluster analysis (CONISS) using the Edwards and CavalliSforza's chord distance measure with TILIA software (Grimm, 1991). The number of zones was confirmed by a broken stick model implemented in R package 'rioja'. The main gradients of floristic variation were first assessed by using detrended correspondence analysis. Because the maximum gradient length of the first axis was 1.81 standard deviation units, the linear ordination technique principal components analysis (PCA) was chosen for subsequent statistical analysis (Lepš and Šmilauer, 2003). PCA focused on inter-species distances. All multivariate ordinations were performed using the CANOCO 4.5 program for Windows (ter Braak and Šmilauer, 2002).

In order to gain quantitative information about mean July air temperature $\left(\mathrm{T}_{\mathrm{Jul}}\right)$ and annual precipitation $\left(\mathrm{P}_{\mathrm{ann}}\right)$ in the past, pollenclimate transfer functions were applied to the fossil pollen spectra from Trout Lake. The modern pollen data set consists of 623 modern surface samples that we extracted from the North American Pollen Database (Grimm, 2000; Whitmore et al., 2005, Version 1.7, updated until 2008) including sites located north of $50^{\circ} \mathrm{N}$ and west of $110^{\circ} \mathrm{W}$. Sites with less than 150 terrestrial pollen grains and spores were excluded. Modern pollen spectra cover a wide range of $\mathrm{T}_{\text {Jul }}\left(2.9\right.$ to $\left.16.7^{\circ} \mathrm{C}\right)$ and $\mathrm{P}_{\mathrm{ann}}(42$ to $1481 \mathrm{~mm}$ ). Those eight samples that had annual precipitation values $>700 \mathrm{~mm}$ have been excluded from the development of the transfer functions for $P_{a n n}$ because of low coverage in the high precipitation range. Transfer functions were developed with weighted averaging partial least squares (WAPLS) regression (second-component model was chosen). Furthermore, modern analogue technique (MAT) with squared chord-distance as similarity measure was applied; the reconstructed $\mathrm{T}_{\text {Jul }}\left(\mathrm{P}_{\mathrm{ann}}\right)$ represents the average of the $\mathrm{k}=4(4)$ closest analogues. That $\mathrm{k}$ has been chosen that in a sequence of models with

Table 1

Summary of accelerator mass spectrometer (AMS) ${ }^{14} \mathrm{C}$ results and calibrated ages from Trout Lake, northern Yukon.

\begin{tabular}{|c|c|c|c|c|c|c|c|}
\hline $\begin{array}{l}\text { Core depth } \\
{[\mathrm{cm}]}\end{array}$ & Material & $\begin{array}{l}\text { Mass } \\
{[\mathrm{mg} \mathrm{C}]}\end{array}$ & $\begin{array}{l}\delta^{13} \mathrm{C} \\
{[\%]}\end{array}$ & $\begin{array}{l}\text { Uncalibrated }{ }^{14} \mathrm{C} \text { age } \\
\text { [yr BP] }\end{array}$ & $\begin{array}{l}\text { Calibrated } \\
2 \sigma \text {-age range } \\
{[\text { cal yr BP] }}\end{array}$ & $\begin{array}{l}\text { Median } \\
2 \sigma \text {-age } \\
\text { [cal yr BP] }\end{array}$ & Lab no. ${ }^{\mathrm{a}}$ \\
\hline 3 & Bryum sp., Amblystegiaceae & 0.63 & -35.8 & $930 \pm 30$ & $925-782$ & 852 & Poz-36442 \\
\hline 66 & Meesia sp., Calliergon giganteum & 1.40 & -35.1 & $5760 \pm 40$ & $6659-6465$ & 6561 & Poz-36443 \\
\hline 176 & Warnstorfia exannulatus & 1.72 & -27.0 & $9550 \pm 50$ & $11,101-10,704$ & 10,917 & Poz-36455 \\
\hline 225 & Drepanocladus sp., Scorpidium sp., Calliergon sp. & 1.58 & -32.9 & $12,770 \pm 70$ & $15,641-14,714$ & 15,164 & Poz-36456 \\
\hline 352 & Amblystegiaceae & 0.56 & -35.7 & $12,880 \pm 80$ & $16,093-14,980$ & 15,397 & Poz-36445 \\
\hline 373 & Undefined moss fragments & 0.92 & -32.8 & $13,140 \pm 80$ & $16,533-15,242$ & 15,961 & Poz-36458 \\
\hline
\end{tabular}

${ }^{\mathrm{a}}$ Poz $=$ Poznan Radiocarbon Laboratory. 
increasing $\mathrm{k}$ produced a first minimum in the root mean square error of the difference between the predicted and observed values for the training set samples. Model performance was tested by leave-oneout cross-validation. The root mean square error of prediction (RMSEP) and the coefficient of determination $\left(\mathrm{r}^{2}\right)$ are $\pm 1.63^{\circ} \mathrm{C}(78 \mathrm{~mm})$ and $0.71(0.54)$ for WAPLS and $\pm 1.35^{\circ} \mathrm{C}(77 \mathrm{~mm})$ and 0.80 (0.54) for MAT, respectively, and thus indicate that the modern data set is suitable for quantitative reconstructions. Calibrations were performed using C2 software (Juggins, 2003).

\section{Results}

\section{Modern limnology}

The oligotrophic Trout Lake is very weakly alkaline ( $\mathrm{pH} 7.4$ to 7.9 ) and its dissolved oxygen content is high $(>20 \mathrm{mg} / \mathrm{l})$. The lake water has a low electrical conductivity, between $82 \mu \mathrm{S} \mathrm{cm}{ }^{-1}$ in August and $138 \mu \mathrm{S} / \mathrm{cm}$ in April (Table 2). With $\delta^{18} \mathrm{O}$ values of approximately $17 \%$ and a deuterium excess ( $d$-excess $\left.=\delta D-8 \delta^{18} \mathrm{O}\right)$ that ranges from $-5.8 \%$ in April to $-7.4 \%$ in August, the hydrological system is semi-closed; evaporation effects lead to enriched $\delta$-values and a reduced $d$-excess compared to modern precipitation data derived from Inuvik $\left(68^{\circ} 18^{\prime} \mathrm{N}, 133^{\circ} 37^{\prime} \mathrm{W}\right.$; IAEA, 2006), which is located about $150 \mathrm{~km}$ east of Trout Lake.

\section{Chronostratigraphy and sediment properties}

The age-depth model was constructed by linear interpolation between the oldest three dates because these dates fall within an overlapping and narrow age range (Table 1). Age extrapolation to the bottom of the sediment core was done accordingly. A squared regression model was used between the youngest four dated samples. Transferring the established age-depth relationship onto the lithostratigraphic units (Fig. 3), which are described in detail in the following, yields four chronostratigraphic periods (Fig. 3) that are discussed in the course of this study. We do not consider an appreciable hardwater reservoir effect because carbonates are absent in Trout Lake sediments and its catchment rocks (Norris, 1977). Moreover, the low electrical conductivity of the lake water and the lake's physical characteristics (i.e., small, mixed,

Table 2

Modern limnological, hydrochemical, and stable water isotope characteristics from Trout Lake, northern Yukon.

\begin{tabular}{llll}
\hline Parameter & Unit & August 2008 & April 2009 \\
\hline Max water depth & $\mathrm{m}$ & & 10.2 \\
Surface water temperature & ${ }^{\circ} \mathrm{C}$ & 11.0 & 0.7 \\
Bottom water temperature & ${ }^{\circ} \mathrm{C}$ & 11.1 & 2.8 \\
$\mathrm{O}_{2}$ & $\mathrm{mg} / \mathrm{L}$ & $\mathrm{n} . \mathrm{a}$. & 21.9 \\
$\mathrm{pH}$ & & 7.4 & 7.9 \\
Electrical conductivity & $\mu \mathrm{c} / \mathrm{cm}$ & 82.1 & 138 \\
$\mathrm{Ca}^{2+}$ & $\mathrm{mg} / \mathrm{L}$ & 9.65 & 15.3 \\
$\mathrm{~K}^{+}$ & $\mathrm{mg} / \mathrm{L}$ & 0.69 & 1.12 \\
$\mathrm{Mg}^{2+}$ & $\mathrm{mg} / \mathrm{L}$ & 3.40 & 5.19 \\
$\mathrm{Na}^{+}$ & $\mathrm{mg} / \mathrm{L}$ & 1.11 & 1.74 \\
$\mathrm{Cl}^{-}$ & $\mathrm{mg} / \mathrm{L}$ & 0.67 & 1.17 \\
$\mathrm{SO}_{4}^{2-}$ & $\mathrm{mg} / \mathrm{L}$ & 16.8 & 27.2 \\
$\mathrm{HCO}_{3}^{-}$ & $\mathrm{mg} / \mathrm{L}$ & 24.9 & 37.8 \\
$\delta^{18} \mathrm{O}$ & $\%$ VSMOW & -17.0 & -17.7 \\
$\delta \mathrm{D}$ & $\%$ VSMOW & -144 & -147 \\
$d^{-e x c e s s}$ & $\%$ VSMOW & -7.4 & -5.8 \\
\hline
\end{tabular}

Note:

Cation and anion contents were determined by inductively coupled plasma-optical emission spectrometry (ICP-OES, Perkin-Elmer Optima $3000 \mathrm{XL}$ ) and ion chromatography (IC, Dionex DX-320), respectively. Hydrogen carbonate concentrations were measured by titration (Metrohm 794 Basic Titrino). $\delta^{18} \mathrm{O}$ and $\delta \mathrm{D}$ ratios were determined with a Finnigan MAT Delta-S mass spectrometer, using the equilibration technique (Horita et al., 1989). Deuterium excess ( $d$-excess $=\delta D-8 \delta^{18} 0$; Dansgaard, 1964) was calculated and provides insight into (i) the water source of the initial precipitation, and (ii) the presence or absence of secondary non-equilibrium fractionation processes. and with an existing outflow) probably lead to a short water-residence time, where hardwater effects are unlikely to exist (e.g., Abbott and Stafford, 1996; Fallu et al., 2004).

\section{Basement (>16 cal ka BP; 405-386 cm)}

The lowermost $20 \mathrm{~cm}$ of the core are composed of bedrock debris. Black shale and siltstone, typical of the Jurassic catchment rocks, showed shattered structures due to the coring process. Geochemical parameters measured within ground bedrock samples serve as background values for interpreting soft sediment values and their relationship to primary production within the lake or its catchment versus bedrock-derived components. The bedrock contains 1.6 to $2.0 \% \mathrm{TOC}$ with a $\delta^{13} \mathrm{C}$ signature of $-24.2 \%$, moderate inorganic carbon ( 0.1 to $1.5 \%$ ), and high sulphur contents ( 0.4 to $8.7 \%$ ) leading to low $\mathrm{C} / \mathrm{S}$ ratios ( 0.2 to 5.3 ; Fig. 3 ). Bedrock debris together with overlying coarse-grained material of unit 1 was mapped as a reflector in the GPR data (Fig. 2c) and provides insight into the basin morphology. This unit represents the bottom of the basin; therefore, we document the complete sediment record since the onset of sediment accumulation in the basin.

\section{Unit 1 (16.0 to $14.8 \mathrm{cal} \mathrm{ka} \mathrm{BP;} 385-225 \mathrm{~cm}$ )}

Black unbedded sand, gravel, and minor amounts of silt and clay make up this unit that covers the latest part of the full-glacial period. Sedimentological properties are homogenous throughout the entire unit and are comparable to the background values of the underlying bedrock in terms of TOC, $\delta^{13} \mathrm{C}$, and $\mathrm{C} / \mathrm{S}$ ratios, and therefore imply low organic-matter production or preservation. At 381-366 cm and $347-330 \mathrm{~cm}$ greenish-gray silty clay lenses were visible. In both intervals the clay lenses can be recognized by a clay peak in the grain-size diagram and a MS minimum (Fig. 3). The MS varies between 13 and 68 SI and the grain-size spectrum is dominated by a high and variable sand content (up to $81 \%$ ) with gravel admixtures. This together indicates a frequently changing depositional environment during the rapid deposition of the lowermost $160 \mathrm{~cm}$ of sediment in a fluvial environment, or at least in a basin episodically traversed by running water. From $231 \mathrm{~cm}$ upwards, unit 1 grades into fine-clastic and compact material of unit 2.

\section{Unit 2 (14.7 to $10.7 \mathrm{ka} ; 224-150 \mathrm{~cm}$ )}

Unit 2 encompasses the period of the late glacial-Holocene transition. The material is silty and clastic-dominated at the bottom. It becomes slightly finer grained and more organic-rich upward, where compact and massive clayey silt with some sand is encountered. Parallel bedding structures are visible in the upper part, and several moss and organic-rich layers are intercalated at 180-176, 172-171, and $160 \mathrm{~cm}$. Sediments at the top of unit 2 are clayey, black, structureless, sticky, and greasy, and with a gradational contact with unit 3. Water content rises sharply by $15 \%$ at the transition between units 1 and 2 , where most sedimentological parameters including sedimentation rate change strongly. MS decreases to minimal values of 4 SI before it rises again with secondary minima at organic-rich layers. TOC is consistently present above $3.5 \%$ with maximum values of ca. $8 \%$ where moss layers occur. Low $\mathrm{C} / \mathrm{N}$ ratios (10 to 12 ) together with low $\mathrm{C} / \mathrm{S}$ ratios (due to high sulfur contents, up to $3.7 \%$ ) and a $\delta^{13} \mathrm{C}$ below $-25 \%$ (Fig. 3 ), which is typical of terrestrial organic matter input, could point towards a preferential loss of organic carbon due to strong organic-matter decomposition. At organic-rich layers, MS drops; moisture, TOC, and C/N ratios peak (Fig. 3), with concurrent minima in $\delta^{13} \mathrm{C}(-28$ to $-27 \%)$. This is typical of a dominance of terrestrial C3 plants (Meyers, 1994).

The sedimentary record between 14.7 and $10.7 \mathrm{cal} \mathrm{ka}$ BP is characterized by episodically changing sedimentological parameters, and therefore indicates several shifts in the driving forces of deposition and organic-matter accumulation. In contrast to unit 1 , which is attributed to full-glacial conditions with a dominance of grain-size variability and high noise in the data, the variability within unit 2 is instead driven by changes in the biogeochemical parameters of Trout Lake and is possible related to climate forcing and fluctuating lake levels. 


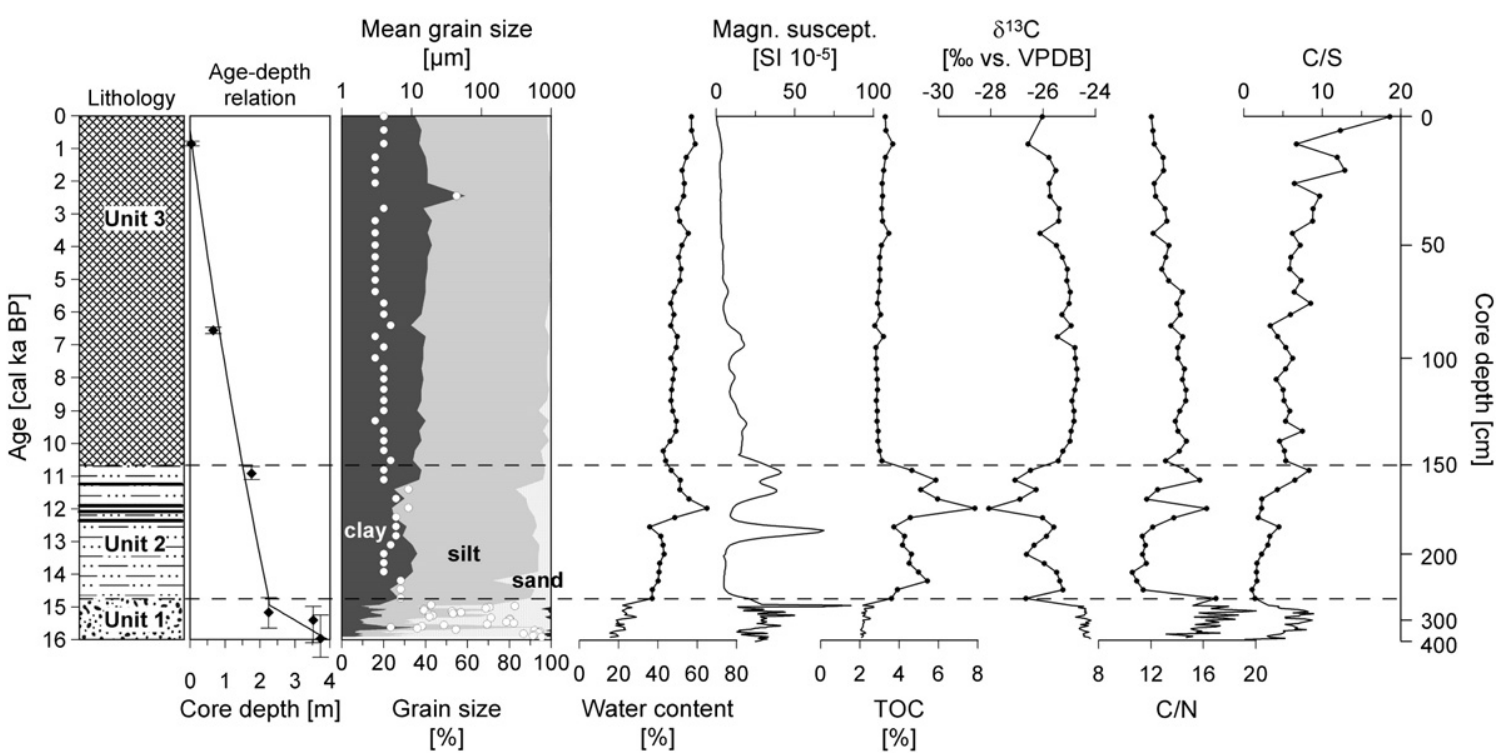

Figure 3. Summary plot of age-depth relationship and lithological, sedimentological, and biogeochemical parameters from Trout Lake, northern Yukon. Linear interpolation ( $\mathrm{y}=$ $0.158 \mathrm{x}-2136.434)$ between the lowermost three dates and a second order polynomial $\left(\mathrm{y}=2.53610^{-7} \mathrm{x}^{2}+0.012 \mathrm{x}-5.499\right)$ between the uppermost dated samples was applied (see also Table 1).

\section{Unit 3 (10.6 cal ka BP to present; 149-0 cm)}

Deposits from unit 3 represent the entire Holocene and appear black, structureless, water-saturated (46 to $59 \%$ water content), and very soft. Most sedimentological properties are almost homogeneous throughout this segment (Fig. 3 ) as indicated by a constant low MS (0 to 9 SI). Very fined-grained and clayey to silty deposits with usually less than $5 \%$ sand dominate, although single scattered clasts up to $0.5 \mathrm{~cm}$ in diameter are present at 58 and $54 \mathrm{~cm}$. These clasts are perhaps due to eolian dispersal of lake-proximal sediments on the ice during winter and are deposited on the lake floor during ice melt. Thin organic-rich layers are visible at $135,128,111.5,91,87,83$, and $67 \mathrm{~cm}$. A thin layer of peat moss covers the sediment surface. Carbonate shells are absent throughout the core except for one small fragment found at $142 \mathrm{~cm}$. Values of inorganic carbon, calculated as the difference between measured TC and TOC, never exceed $0.4 \%$. Therefore, lake sediments are regarded as largely carbonate-free. TOC is only present at less than $2 \%$ above the background value of the underlying bedrock, and shows a terrestrial C3 carbon isotopic signature of -26.6 to $-24.7 \%$ or $\delta^{13} \mathrm{C}$. Low $\mathrm{C} / \mathrm{N}$ ratios rise slightly, together with TOC contents, towards the surface (Fig. 3), and indicate strong decomposition of organic carbon and nitrogen fixation.

Sedimentation rates were very low during the Holocene $(\leq 0.17 \mathrm{~mm} / \mathrm{yr})$ and partly explain the lack of variability in biogeochemical parameters. Well-aerated surface deposits exposed for a long time due to slow sedimentation rates in oxygen-rich lake water may lead to nearly complete oxidation of organic matter and unfavorable conditions for carbonate preservation in ion-poor lake water (e.g., $\mathrm{HCO}_{3}^{-}$depleted). Based on the homogeneity of sediment properties throughout the Holocene, we infer few changes in sediment input, sedimentation rate, or lake level; however, any such changes might be concealed because the sampling resolution, especially throughout the Holocene, is rather low, with a 300-to-400 year inter-sample resolution.

Pollen

\section{Pollen zonation}

The Trout Lake pollen percentage diagram is divided into four pollen zones (PZ) based on the information from CONISS (Fig. 4).

PZ 1 (16 to 15.1 cal ka BP): the pollen assemblages prior to $\sim 15 \mathrm{cal}$ ka BP indicates a dry herbaceous tundra as they are dominated by Poaceae ( $>37 \%$ ), Artemisia ( 17\%), and Cyperaceae (5 to $9 \%$ ), high percentages of Brassicaceae ( 4.5\%), and increasing values of Betula (10 to $24 \%$ ) towards zone 2 . PZ 1 exhibits the lowest pollen concentration, and low percentages of arboreal pollen, aquatic taxa, and spores.

PZ 2 (15.0 to 10.7 cal ka BP): In this zone Betula rises sharply, reaching maximum values of $>70 \%$ between $\sim 14.0$ and 12.9 cal ka BP. Salix is consistently present above $5 \%$ while Cyperaceae slightly increases ( 8 to $20 \%$ ) and Poaceae drops to less than 15\%. Taxa that indicate disturbed ground or dry edaphic conditions such as Artemisia, Brassicaceae, Asteraceae, Ranunculaceae, and Saxifragaceae are consistently present. A notable drop in Betula percentages with a parallel increase in Poaceae and Cyperaceae characterizes PZ 2 between 12.6 and $11.5 \mathrm{cal} \mathrm{ka} \mathrm{BP,}$ which may be coeval with the YD stadial (Fig. 4). By the end of PZ 2 towards the early Holocene at $\sim 11.2$ cal ka BP Populus occurs for the first time, although in small amounts.

PZ 3 (10.6 to 5.0 cal ka BP): Betula is still dominant with secondary influences of Cyperaceae, Salix, Ericaceae, and spores of Sellaginella and Sphagnum. Populus reaches its maximum of slightly more than 5\% and slowly decreases afterwards. Picea starts to occur at frequencies $>1 \%$ at $9.8 \mathrm{cal}$ ka BP and exhibits constant values above $4 \%$ after 8.9 cal ka BP, but never exceeds 7\% throughout the record. Towards the end of zone 3 Alnus occurs for the first time with values above 5\% at $\sim 7.3$ cal ka BP, followed by a rapid increase.

PZ 4 (4.9 cal ka BP to present): In this zone Betula and Salix decrease until $4 \mathrm{cal} \mathrm{ka}$ BP and then remain constant at about 25 to $30 \%$ and around $1 \%$, respectively. Alnus becomes dominant by $\sim 5$ cal ka BP, reaching maximum values of around $50 \%$ after 4.3 cal ka BP. Ericaceae show a minor maximum in the past $3.0 \mathrm{cal}$ ka BP. Isoetes spores begin to occur in PZ 3 at $\sim 5.3 \mathrm{cal} \mathrm{ka} \mathrm{BP}$ and remain the dominant aquatic taxon until present.

\section{Principal component analysis, temperature and precipitation} reconstruction

The first two axes of the PCA explain $86.7 \%$ of the variation in the pollen data (Fig. 5a). The length of a vector in the biplot indicates how strongly the variable is related to the displayed ordination (ter Braak and Šmilauer, 2002). Hence, Alnus, Isoetes, Picea, and Ericaceae are positively correlated with the first axis in descending order of correlation, whereas Salix, Artemisia, and Ranunculaceae are negatively correlated. Taxa positively correlated with PCA axis 2 include Poaceae and Artemisia, whereas Betula, Cyperaceae, and Sphagnum are negatively 


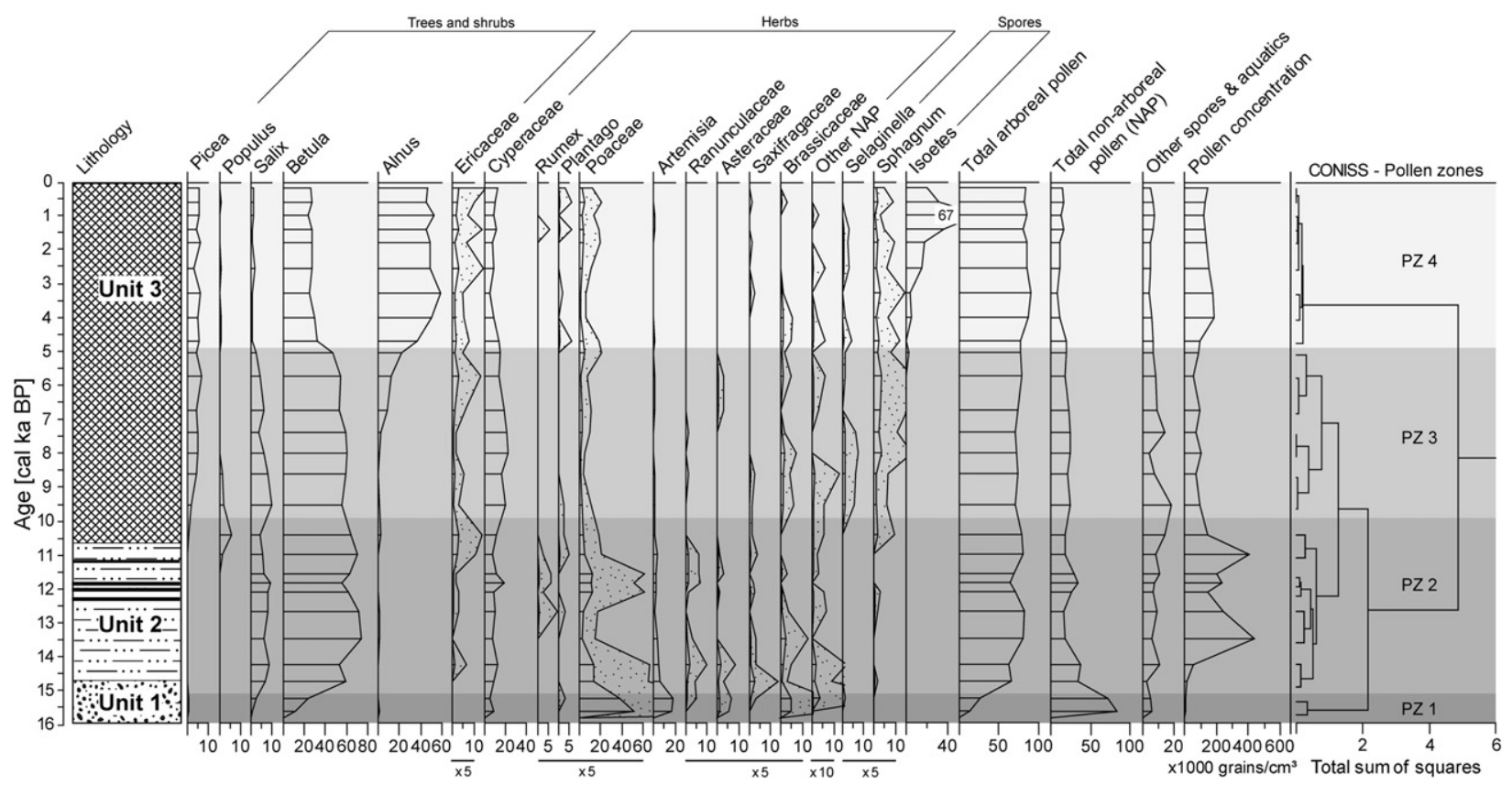

Figure 4. Pollen percentage diagram from Trout Lake, northern Yukon. Other non-arboreal pollen (NAP) comprise Potentilla, Laminaceae, Papaveraceae, Fabaceae, Epilobum, Thalictrum, Caryophyllaceae, Chenopodiaceae, Rubus, Apiaceae, and Polygonum. Other spores and aquatics comprise Pteridium, Potamogeton, Myrriophyllum, Equisetum, Bryidae, Pediastrum, and Botryococcus. Note varying exaggeration factors for selected taxa.

correlated, and variations of Populus are poorly represented in the plot. The separation of species into distinct groups in the PCA ordination relates to species-specific ecological preferences, most probably related to edaphic conditions and climate.

Sample scores on the first axis are negative until $\sim 7$ cal ka BP and show a generally increasing trend from $16.0 \mathrm{cal}$ ka BP until 3.6 cal ka BP (Fig. 5b). Scores remain above unity after 4.3 cal ka BP. Sample scores on PCA axis 2 decrease from maximum values at $16.0 \mathrm{cal} \mathrm{ka}$ BP until $\sim 13$ cal ka BP and show a similar trend as sample scores on the first axis since $\sim 10 \mathrm{cal}$ ka BP. This is in contrast to the period between $\sim 14$ and $11 \mathrm{cal} \mathrm{ka} \mathrm{BP}$, when sample scores on both axes run contrary to one another (Fig. 5b). Mean summer insolation (July, $60^{\circ} \mathrm{N}$; Laskar et al., 2004) since $16 \mathrm{cal} \mathrm{ka} \mathrm{BP}$ as well as non-pollen palynomorphs (i.e., Sphagnum and Isoetes spores) and TOC are plotted in the PCA as inactive (Fig. 5a) in order to enable qualitative assumptions about the relationship of regional vegetation response on changing supraregional environmental parameters represented by the supplement. In this context, summer insolation serves as a proxy for orbitally controlled summer temperature variations (Huntley and Prentice, 1988; Huybers, 2006). Summer insolation is slightly negatively correlated to the second axis. Sphagnum and Isoetes spores are positively related to the first axis; TOC is insignificant.

Pollen-inferred $\mathrm{T}_{\mathrm{Jul}}$ were lowest during the late glacial between 16.0 and $13.7 \mathrm{cal}$ ka BP but then ameliorated rapidly towards modern temperature conditions (Fig. 6). Results of both applied reconstruction methods indicate a sudden decrease in $\mathrm{T}_{\text {Jul }}$ of $1.5^{\circ} \mathrm{C}$ between 12.9 and $11.2 \mathrm{cal} \mathrm{ka} \mathrm{BP}$, followed by an increase to near-modern values at $7 \mathrm{cal} \mathrm{ka} \mathrm{BP.} \mathrm{T}_{\text {Jul }}$ has remained stable during the past $4.3 \mathrm{cal}$ ka BP. Results based on WAPLS are similar to those based on MAT; however, the absolute reconstructed temperature range is larger (WAPLS: 5.8

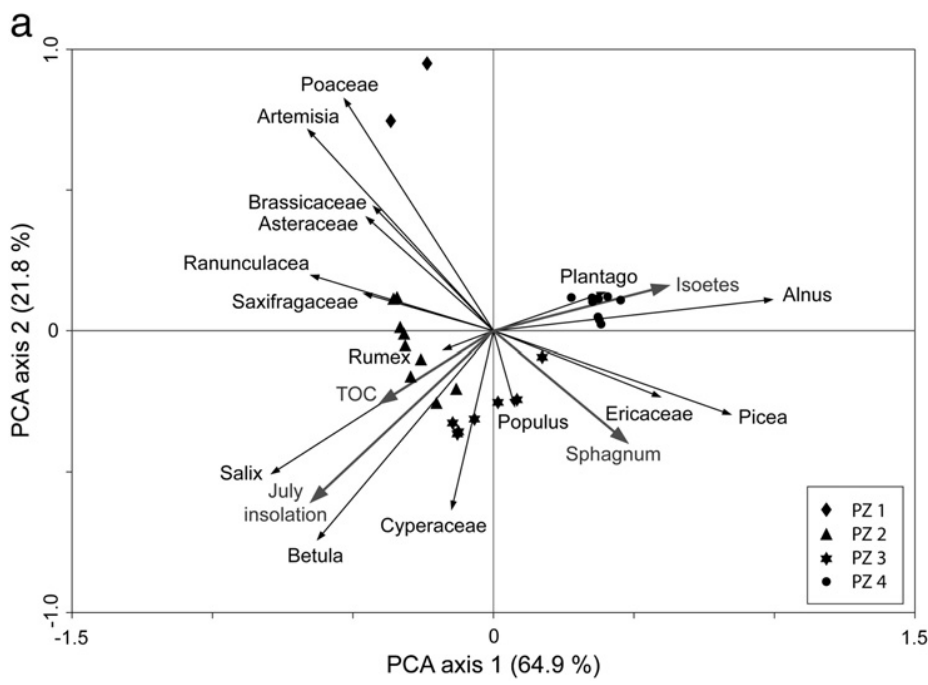

b

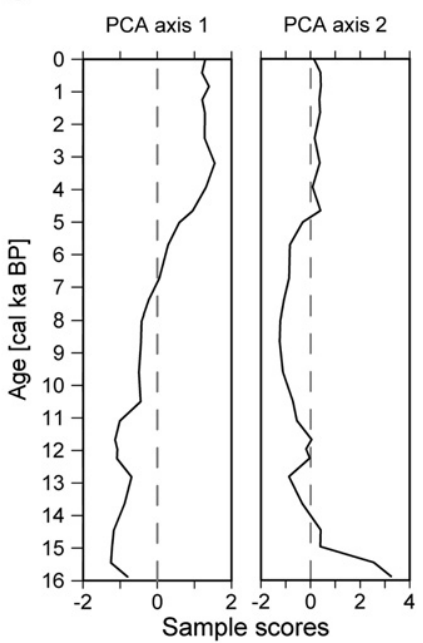

Figure 5. Summary of principal component analysis (PCA). (a) PCA biplot for pollen data. Inactive supplementary parameters (July insolation, TOC, Sphagnum, Isoetes) are shown in grey. Symbols are keyed to the Pollen Zones (PZs); see also Fig. 4. (b) Time series of sample scores for PCA axes 1 and 2 from Trout Lake, northern Yukon. 
to $11.5^{\circ} \mathrm{C}$; MAT: 6.4 to $10.9^{\circ} \mathrm{C}$ ). The temperature increase at the late glacial-Holocene transition is more pronounced in the applied WAPLS, whereas the MAT shows a more pronounced early Holocene warming between 11.2 and 8.9 cal ka BP with relatively stable conditions until today in both reconstructions (Fig. 6).

Reconstructed annual precipitation $\left(\mathrm{P}_{\mathrm{ann}}\right)$ ranges between 89 and $263 \mathrm{~mm}$ with values consistently below $200 \mathrm{~mm}$ during the late glacial between 16.0 and $11.0 \mathrm{cal}$ ka BP. Both applied transfer functions show low or even minimal precipitation between 12.9 and $11.5 \mathrm{cal} \mathrm{ka} \mathrm{BP}$ and an increase during the early Holocene, however with still lower values than during the last $\sim 5 \mathrm{ka}$. Based on MAT, precipitation was always greater than $200 \mathrm{~mm}$ since $5.3 \mathrm{cal} \mathrm{ka} \mathrm{BP}$ and remained relatively stable. The precipitation record based on WAPLS is more variable and both transfer functions do not always parallel the temperature reconstruction, especially during the early and middle Holocene.

\section{Discussion}

Formation and development of Trout Lake in ice-marginal eastern Beringia

Lake sediment accumulation in Trout Lake began around 16 cal ka BP during the waning stages of the late Wisconsin glaciation. Welsh and Rigby (1971) recognized that lakes are uncommon along the unglaciated parts of the YCP and in the adjacent foothills of the British Mountains. One exception is Trout Lake that may have formed as a plunge-pool lake in the ancient surface of the Babbage River drainage (Welsh and Rigby, 1971). The Babbage River is entrenched 20 to $30 \mathrm{~m}$ below the pediment surface on Jurassic shale near Trout Lake with four distinct river terraces; the uppermost terrace is well above the proximate (eastern) lake shore and the current lake level.

\section{Late glacial drainage diversion-initial sedimentation}

The initial lake sedimentation at $16 \mathrm{cal} \mathrm{ka}$ BP was characterized by rapid input of sand with admixtures of clay, silt, and gravel of local provenance as indicated by the predominance of black shale particles. Rapid grain-size alternations with silty interbeds and intercalated clay lenses suggest frequently changing water volumes and flow velocities. Bioproductivity and organic-matter input were low due to harsh climate conditions and sparse vegetation in the lake catchment. Depositional conditions during the waning stages of the full glacial were directly influenced by the proximity of the LIS, which crossed the Babbage River valley northeast of Trout Lake and that remained close to its northwestern limit until 15 to $14 \mathrm{cal} \mathrm{ka} \mathrm{BP} \mathrm{(Dyke} \mathrm{and}$ Prest, 1987; Dyke et al., 2002, 2003; Fig. 1b). The LIS most likely blocked direct northern drainage into the Beaufort Sea, resulting in a drainage diversion that forced LIS meltwater and local drainage southward up the Babbage River and its confluences. Similarly, in the central Yukon, the LIS impounded the eastward drainage of the paleo-Porcupine River at McDougal Pass (e.g., Duk-Rodkin and Hughes, 1994) and caused westward drainage diversion into the Yukon River (e.g., Duk-Rodkin et al., 2004). The southern slopes of the British Mountains all belonged to the paleo-Porcupine watershed (Duk-Rodkin and Hughes, 1995); therefore, the Babbage River and its tributaries likely served as the major proglacial drainage path to the north along the oscillating LIS margin during the latest part of the full glacial. Dyke and Prest (1987) inferred asynchronous ice retreat for the northwest LIS margin that remained close to its limits until $\sim 15{ }^{14} \mathrm{C}$ ka BP while Murton et al. (2007) argued, on the basis of a series of optically stimulated luminescence ages, that deglaciation on Tuktoyaktuk Peninsula commenced between 16 and $14 \mathrm{ka}$ ago. This line of evidence provides reasonable support for the hypothesis that with the onset of substantial ice-margin recession, episodic spillovers may have entered the Trout Lake basin at its southeastern end via a narrow valley incised into the uppermost Babbage River terrace and might also have filled the nearby smaller lakes (Figs. 1b and 2b).

\section{Stabilizing lake environment}

Beginning with the B/A interstadial ( 14.7 to 13.0 cal ka BP), Trout Lake was a permanently water-filled basin with variable inputs of clay-, silt-, and sand-sized material. Coarser particles were probably wind-driven or derive from spring snowmelt from incompletely vegetated slopes. We observed eolian transport of clasts up to $1.5 \mathrm{~cm}$ in diameter onto the Trout Lake ice was observed during a major windstorm in April 2009. Low C/S ratios point towards anoxic bottom water conditions in a shallow water body with still short ice-free periods under mats of plant detritus or algae, which inhibited surface sediment aeration. On millennial time scales, sedimentation history at Trout Lake is stable throughout the Holocene and is decoupled from the timing of vegetation succession as inferred from palynological results. The dominance of fine-grained deposits and low TOC contents suggest high lake levels, densely vegetated slopes that prevent mass-wasting events and low primary production in combination with low preservation capability of organic matter in an oligotrophic and well-aerated lake.

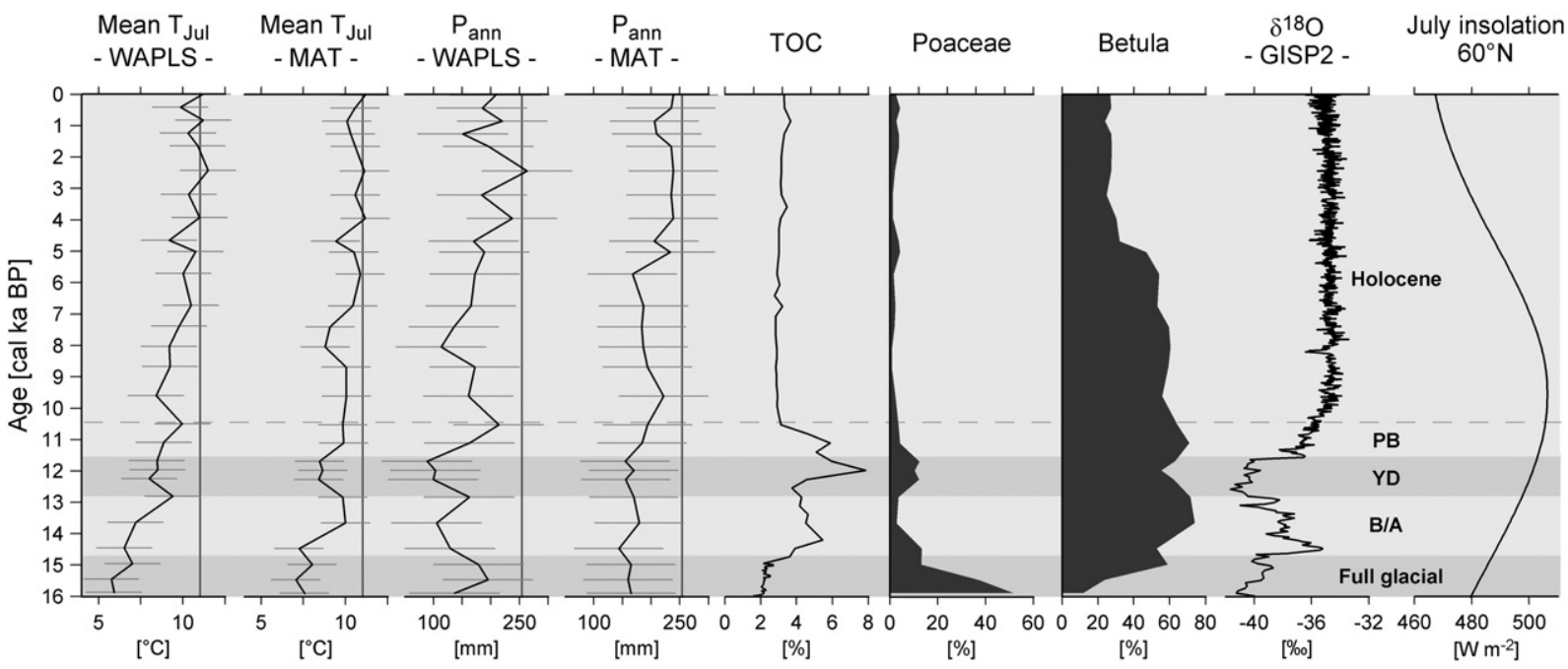

Figure 6. Summary plot of temperature and precipitation reconstructions, total organic carbon (TOC) of lake sediments, and selected pollen percentages (Poaceae, Betula) from Trout Lake compared with the oxygen isotope curve from GISP2 ice core (Greenland, $72^{\circ} 35^{\prime} \mathrm{N}, 38^{\circ} 28^{\prime} \mathrm{W}$; Grootes and Stuiver, 1997) and mean summer insolation (July, 60 ${ }^{\circ} \mathrm{N}$; Laskar et al., 2004) of the last $16 \mathrm{cal}$ ka BP. Reconstructed mean July air temperatures ( $\mathrm{T}_{\text {Jul }}$ ) and annual precipitation ( $\mathrm{P}_{\text {ann }}$ ) are based on pollen using weighted averaging partial least squares regression (WAPLS) transfer function and the modern analogue technique (MAT). The root mean square errors of prediction are shown as horizontal lines. Vertical lines represent modern mean July air temperature and annual precipitation $\left(11.2^{\circ} \mathrm{C}, 254 \mathrm{~mm}\right)$ at Shingle Point (Environment Canada, 2000). 
Environmental change during the late glacial-Holocene transition ( 16 to $11.6 \mathrm{cal} \mathrm{ka} \mathrm{BP}$ )

\section{Latest full glacial}

During the latest part of the full glacial (16.0 to $14.7 \mathrm{cal}$ ka BP), a sparse vegetation, predominantly characterized as herb-dominated tundra, with communities indicating dry conditions and disturbed ground (Poaceae, Artemisia, Brassicaceae) together with low pollen concentration (PZ 1), covered the ground in the direct vicinity of the Trout Lake basin. Inferred $\mathrm{T}_{\text {Jul }}$ of 6 to $7^{\circ} \mathrm{C}$ are the coldest of the whole record and the reconstructed $\mathrm{P}_{\mathrm{ann}}$ is 50 to $120 \mathrm{~mm}$ lower than today (Fig. 6). This is in good agreement with significantly lower-thanmodern chironomid-inferred $\mathrm{T}_{\text {Jul }}$ from Hanging Lake (Kurek et al., 2009) and up to $4^{\circ} \mathrm{C}$ cooler-than-modern $\mathrm{T}_{\text {Jul }}$ which lasted until $\sim 15$ cal ka BP based on a pollen-derived quantitative reconstruction using the MAT across eastern Beringia (Viau et al., 2008).

\section{Bølling/Allerød}

The abrupt climate warming during the $\mathrm{B} / \mathrm{A}(\sim 14.7$ to $13 \mathrm{cal} \mathrm{ka} \mathrm{BP})$ is well-recorded in the GISP2 ice-core record from central Greenland and matches the Trout Lake record (Fig. 6), where herbal taxa decline, whereas Betula and Salix percentages rise rapidly in the pollen record. We therefore infer a rapid change from herbaceous tundra to Betula-Salix shrub tundra and increased vegetation coverage indicated by increasing pollen concentrations. High pollen concentrations between $\sim 14$ and 11 cal ka BP might also be related to a greater proximity of the coring site to the lake margin as a result of shallower water conditions and a smaller lake size.

$\mathrm{T}_{\text {Jul }}$ increased by about $3^{\circ} \mathrm{C}$ in eastern Beringia (Viau et al., 2008; Bunbury and Gajewski, 2009) most probably as a result of rising summer insolation, the retreating LIS front (Dyke and Prest, 1987; Dyke et al., 2002), and the still $\sim 50$ to $90 \mathrm{~m}$ lower (than present day) glacio-eustatic sea level of the Beaufort and Chukchi seas (Hill et al., 1985; Keigwin et al., 2006). The LIS extent was probably still large enough to maintain an anticyclonic influence in eastern Beringia, especially under sustained split jet stream conditions (Bartlein et al., 1991), which, together with large exposed shelf areas and an almost permanent sea-ice cover (Scott et al., 2009), would enhance continentality. Similar to the Hanging Lake record (Kurek et al., 2009), $\mathrm{T}_{\text {Jul }}$ at Trout Lake rose during the B/A up to near-modern values, or are at least within the range of modern summer temperatures, taking into account a RMSEP of $\sim 1.5^{\circ} \mathrm{C}$. Sediments show a concurrent increase in TOC content, probably due to increased vegetation cover in the catchment, low lake level, and dry climate conditions favoring organic matter preservation.

\section{Younger Dryas}

The temperature rise of the $\mathrm{B} / \mathrm{A}$ interstadial at Trout Lake reverses abruptly at 12.9 cal ka BP (Fig. 6), which is coeval with the onset of the YD stadial in the GISP2 record (Grootes and Stuiver, 1997). $T_{\text {Jul }}$ dropped by about $1.5^{\circ} \mathrm{C}$ compared to the $\mathrm{B} / \mathrm{A}$ interstadial and the subsequent Preboreal (PB) to early Holocene and were roughly 2.5 to $3.0^{\circ} \mathrm{C}$ below modern conditions (Fig. 6). Cold- and dry-adapted non-arboreal pollen taxa (Poaceae, Ranunculaceae, Rumex, Asteraceae, Artemisia) briefly increase concurrently with a drop in pollen concentration mainly caused by decreasing Betula input. A similar increase of Artemisia, which is indicative of a cold and dry climate, is documented during the YD in records from the southern Yukon (Cwynar, 1988; Bunbury and Gajewski, 2009). Sustained dryness at Trout Lake during the YD is supported by an inferred $\mathrm{P}_{\mathrm{ann}}$ as low as $90 \mathrm{~mm}$ (Fig. 6). Evidence for a YD stadial is known from lake sediments in southern and western Alaska (Engstrom et al., 1990; Abbott et al., 2000; Bigelow and Edwards, 2001; Hu et al., 2002, 2006; Mann et al., 2002) with the strongest impact on coastal sites close to the Pacific (Mikolajewicz et al., 1997; Kokorowski et al., 2008). In addition, ice wedges (Meyer et al., 2010) and fossil beetle assemblages (Elias, 2000) from northern Alaska have recorded a large-scale cooling of winter and summer temperatures, respectively, between 12.8 and 11.5 cal ka BP. In eastern Beringia, Viau et al. (2008) and Bunbury and Gajewski (2009) reconstructed a spatially robust temperature decrease during the YD, whereas the Hanging Lake record does not show major temperature variations during the past $15 \mathrm{cal}$ ka BP except for a neoglacial cooling (Kurek et al., 2009).

Environmental development since the early Holocene (11.5 cal ka BP to present)

\section{Early Holocene (thermal maximum?)}

A summer insolation maximum during the early Holocene in combination with a further retreat of the Laurentide Ice Sheet (LIS) led to a warmer-than-modern period across the western Arctic known as the Holocene thermal maximum (HTM), with maximum summer warmth in eastern Beringia between ca. 11 and 9 cal ka BP (Ritchie et al., 1983; Kaufman et al., 2004). Pollen and plant macrofossil evidence (Picea and Populus) up to 75 to $100 \mathrm{~km}$ north of its present range indicate substantially warmer conditions than today (Cwynar, 1982; Ritchie, 1984; Nelson and Carter, 1987; Anderson, 1988; Vermaire and Cwynar, 2010). Although Populus pollen occur briefly in the Trout Lake record, the early Holocene $\mathrm{T}_{\text {Jul }}$ reconstructed by both WAPLS and MAT approach modern values (within the range of error) but do not exceed modern summer temperatures. A similar result emerges from Viau et al. (2008) for temperature reconstructions across eastern Beringia. Nevertheless, we have to take into account that vegetation is not solely linked to summer temperature but also to available moisture. The missing HTM in the Trout Lake temperature record might be explained by sustained low net precipitation in combination with increased evaporation during the warming of the early Holocene. Moisture availability probably remained low until $\sim 8$ cal ka BP as reported by Pienitz et al. (2000) for the central Yukon, and did not reach modern conditions before 5 to 4 cal ka BP (Anderson et al., 2005; Bunbury and Gajewski, 2009). Similar results emerge from the Trout Lake record with $\mathrm{P}_{\mathrm{ann}}$ values consistently below modern (Fig. 6). We therefore infer that a moisture-limited spread of vegetation (Cwynar, 1988) dampened the reconstructed summer temperature signal and thereby obscured the Arctic-wide HTM in our pollen record.

\section{Holocene moisture pattern and migration of key taxa (Picea, Alnus)}

MAT inferred $\mathrm{P}_{\mathrm{ann}}$ increases from the end of the YD until $\sim 5.0$ cal ka BP and agrees with simultaneously rising Alnus, Picea, Sphagnum, Ericaceae, and Isoetes percentages. These taxa are positively correlated to PCA axis 1 (Fig. 5) and are known to reflect increased moisture (e.g., Cwynar, 1988; Cwynar and Spear, 1995; Szeicz et al., 1995; Lacourse and Gajewski, 2000). Alnus-Betula shrub tundra with wet heath communities (Ericaceae, Cyperaceae, Sphagnum) covers the landscape around Trout Lake since $\sim 5$ cal ka BP (PZ 4, Fig. 4) indicating stable and near-modern moisture and temperature conditions on a millennial time scale. Picea, a frequently studied example in terms of tree-line migration in the western Arctic, has been permanently present in the Yukon and the adjacent Northwest Territories (NWT) since $\sim 11$ cal ka BP (e.g., Ritchie, 1984; Wang and Geurts, 1991; Vermaire and Cwynar, 2010). Picea has likely grown at a stable distance from Trout Lake since 9 cal ka BP but never in direct vicinity because Picea pollen percentages remain consistently low $(\leq 6 \%)$. Picea likely survived the LGM in eastern Beringia (Brubaker et al., 2005; Anderson et al., 2006), spread undirected, and arrived almost simultaneously in southwestern Alaska, the Yukon, and the Tuktoyaktuk Peninsula (NWT) (e.g., Ritchie, 1984; Wang and Geurts, 1991; Brubaker et al., 2005).

With a further lag of $\sim 1000$ years, Alnus entered the northern Yukon by $\sim 8$ cal ka BP, as supported by the Hanging Lake pollen record (Cwynar, 1982), although its presence has been demonstrated in the southern Yukon since 14 cal ka BP (Lacourse and Gajewski, 2000) and Alnus likely survived the LGM in eastern Beringian refugia (Brubaker et al., 2005). Alnus is believed to have been growing near 
Trout Lake by $\sim 7$ cal ka BP, and it has been the dominant pollen producer since $\sim 5$ cal ka BP. Picea, Alnus, and Ericaceae together with Sphagnum and Isoetes spores indicate substantially increasing moisture availability since the middle Holocene. Slowly decreasing temperatures since the termination of the HTM (Ritchie, 1984; Kaufman et al., 2004) in combination with increasing $\mathrm{P}_{\text {ann }}$ may have led to paludification and a higher water table, also in response to increased permafrost aggradation that culminated in the middle Holocene (Cwynar and Spear, 1995; Vardy et al., 1997). Declining Beaufort Sea sea-ice coverage since $\sim 9$ cal ka BP (Schell et al., 2008) in combination with a rising glacio-eustatic sea level approaching the modern coastline are likely to have allowed enhanced moisture supply to the northern Yukon in summer. The area became increasingly proximate to an oceanic moisture source, and thus evolved from a continental site during the late glacial and early Holocene into a maritime environment (Burn, 1997; Kaufman et al., 2004; Fritz et al., 2012).

Comparison of the two existing paleoenvironmental records from Trout Lake

The midge-inferred temperature reconstructions based on lake sediments from Trout Lake by Irvine et al. (2012) provide excellent control for our record and an important opportunity for comparisons from a data-poor region. Both chronologies fit very well and the two quantitative paleoclimate reconstructions based on independent proxy data (chironomids in Irvine et al., 2012; pollen in this study) allows to conclude the following: (1) Both mean $\mathrm{T}_{\text {Jul }}$ records indicate significantly colder-than-modern climate conditions during the latest part of the full glacial. (2) Late glacial warming with similar temperature amplitudes and magnitudes, as shown in both records, began around 14.4 cal ka BP. (3) A temperature minimum occurred during a period that is coeval with the Younger Dryas stadial, with similar temperature amplitudes between 1.0 and $1.5^{\circ} \mathrm{C}$. Notably, Irvine et al. (2012) do not see a vegetation response to YD cooling in their pollen spectrum, though they recognize a decrease in pollen influx and infer reduced productivity on the landscape. In contrast, our pollen spectrum clearly shows an increase in cold- and dry-adapted non-arboreal pollen taxa and a decrease in Betula during the same interval. (4) Chironomid-inferred summer temperatures reveal a period of consistently warmer-than-modern conditions from about 10.8 to $9.8 \mathrm{cal} \mathrm{ka} \mathrm{BP}$, representing the Holocene thermal maximum, with maximum temperatures of $12.6^{\circ} \mathrm{C}$, about $2.2^{\circ} \mathrm{C}$ above modern (Irvine et al., 2012). The pollen spectra from both studies and our pollen-derived temperature reconstructions, however do not clearly show a vegetation response to early Holocene warming, except for a brief increase in Populus pollen. This once more highlights the importance of precipitation when considering a vegetation response to climate change. Based on our precipitation reconstructions, we suggest that vegetation was unable to respond adequately to an early Holocene thermal maximum because of limited moisture availability. We conclude that the combined perception of the results presented in both studies provide excellent and independent control on the paleoclimate development in the northern Yukon Territory.

\section{Conclusions}

Sedimentological and palynological studies together with multivariate statistics provide a detailed view on the sedimentation, vegetation, and temperature history from the northern Yukon Territory during the past 16 cal ka BP. Using this approach, we discovered the following:

1. As final deglaciation of the northwestern margin of the LIS commenced, drainage diversion caused spillover of glacial meltwater to feed the bedrock basins close to the Babbage River and initiated lake sedimentation in unglaciated northeastern Beringia.

2. Quantitative July air temperature reconstructions indicate a rapid climate warming by $\sim 4^{\circ} \mathrm{C}$, from cold full-glacial conditions towards the B/A interstadial, followed by a distinct YD stadial, which had not previously been reported for the northern Yukon.

3. The YD in continental easternmost Beringia was characterized by $\sim 2.5$ to $3.0^{\circ} \mathrm{C}$ lower-than-modern July air temperatures and low annual net precipitation of 90 to $170 \mathrm{~mm}$.

4. Limited moisture availability in the northern Yukon during increasing temperatures across the western Arctic in the early Holocene may have been responsible for a concealed HTM. A middle to late Holocene moisture increase throughout eastern Beringia with near-modern temperatures and precipitation supported the establishment of an extensive alder/birch shrub tundra north of the current arctic tree line.

\section{Acknowledgments}

We thank the Parks Canada office (Ivvavik National Park) and the Aurora Research Institute-Aurora College (ARI) in Inuvik, NWT for administrative and logistical support. This study was partly funded by the German Science Foundation (DFG; Project No. LA 2399/3-1), the International Bureau of the German Federal Ministry of Education and Research (BMBF; Project No. CAN 08/A07, CAN 09/001), and by a doctoral fellowship awarded to M. Fritz by the German Federal Environmental Foundation (DBU). Analytical work at AWI received great help from Catalina Gebhardt, Ute Bastian, Antje Eulenburg, Christiane Funk, Hanno Meyer, Frank Günther, and Juliane Klemm as well as from Birgit Plessen (GeoForschungsZentrum Potsdam, Germany). Gerald Müller and Samuel McLeod assisted in the field. We thank Frank Kienast (Senckenberg Research Institute, Weimar, Germany) and Romy Zibulski (AWI) for plant identification and Candace O'Connor (University of Alaska, Fairbanks, Alaska) for language revision. Both anonymous reviewers are thanked for their critical discussion of the manuscript. Finally, we appreciate the valuable comments of the editorial board of the journal (Derek Booth, Dan R. Muhs, and Michael A. O'Neal) that improved the paper.

\section{Appendix A. Supplementary data}

Supplementary data associated with this article can be found in the online version, at http://dx.doi.org/10.1016/j.yqres.2012.07.007. These data include Google maps of the most important areas described in this article.

\section{References}

Abbott, M.B., Stafford Jr., T.W., 1996. Radiocarbon geochemistry of modern and ancient arctic lake systems, Baffin Island, Canada. Quaternary Research 45, 300-311.

Abbott, M.B., Finney, B.P., Edwards, M.E., Kelts, K.R., 2000. Lake-level reconstruction and paleohydrology of Birch Lake, central Alaska, based on seismic reflection profiles and core transects. Quaternary Research 53, 154-166.

Anderson, P.M., 1988. Late quaternary pollen records from the Kobuk and Noatak river drainages, northwestern Alaska. Quaternary Research 29, 263-276.

Anderson, L. Abbott, M.B., Finney, B.P. Edwards, M.E., 2005. Palaeohydrology of the southwest Yukon Territory, Canada, based on multiproxy analyses of lake sediment cores from a depth transect. The Holocene 15, 1172-1183.

Anderson, L.L., Hu, F.S., Nelson, D.M., Petit, R.J., Paige, K.N., 2006. Ice-age endurance: DNA evidence of a white spruce refugium in Alaska. Proceedings of the National Academy of Sciences 103, 12447-12450.

Bartlein, P.J., Anderson, P.M., Edwards, M.E., McDowell, P.F., 1991. A framework for interpreting paleoclimatic variations in Eastern Beringia. Quaternary International 10-12, 73-83.

Beug, H.-J., 2004. Leitfaden der Pollenbestimmung für Mitteleuropa und angrenzende Gebiete. Dr. Friedrich Pfeil Verlag, Munich. (in German).

Bigelow, N.H., Edwards, M.E., 2001. A 14,000 yr paleoenvironmental record from Windmill Lake, Central Alaska: Late glacial and Holocene vegetation in the Alaska range. Quaternary Science Reviews 20, 203-215.

Briner, J.P. Kaufman, D.S, Werner, A., Caffee, M. Levy, L, Manley, W.F., Kaplan, M.R. Finkel, R.C., 2002. Glacier readvance during the late glacial (Younger Dryas?) in the Ahklun Mountains, southwestern Alaska. Geology 30, 679-682.

Brubaker, L.B., Anderson, P.M., Hu, F.S., 2001. Vegetation ecotone dynamics in southwest Alaska during the Late Ouaternary. Quaternary Science Reviews 20, 175-188.

Brubaker, L.B., Anderson, P.M., Edwards, M.E., Lozhkin, A.V., 2005. Beringia as a glacial refugium for boreal trees and shrubs: new perspectives from mapped pollen data. Journal of Biogeography 32, 833-848.

Bunbury, J., Gajewski, K., 2009. Postglacial climates inferred from a lake at treeline, southwest Yukon Territory, Canada. Quaternary Science Reviews 28, 354-369. 
Burn, C.R., 1997. Cryostratigraphy, paleogeography, and climate change during the early Holocene warm interval, western Arctic coast, Canada. Canadian Journal of Earth Sciences 34, 912-925.

Cwynar, L.C., 1982. A Late-Quaternary vegetation history from Hanging Lake, northern Yukon. Ecological Monographs 52, 1-24.

Cwynar, L.C., 1988. Late Quaternary vegetation history of Kettlehole Pond, southwestern Yukon. Canadian Journal of Forest Research 18, 1270-1279.

Cwynar, L.C., Spear, R.W., 1995. Paleovegetation and paleoclimatic changes in the Yukon at 6 ka BP. Géographie Physique et Quaternaire 49, 29-35.

Dansgaard, W., 1964. Stable isotopes in precipitation. Tellus 16, 436-468.

Duk-Rodkin, A., Hughes, O.L., 1994. Tertiary-quaternary drainage of the pre-glacial Mackenzie basin. Quaternary International 22-23, 221-241.

Duk-Rodkin, A., Hughes, O.L., 1995. Quaternary geology of the northwest part of the central Mackenzie Valley corridor, Northwest Territories. Geological Survey of Canada Bulletin 458, 45p.

Duk-Rodkin, A., Barendregt, R.W., Froese, D.G., Weber, F., Enkin, R., Smith, I., Zazula, G.D., Waters, P., Klassen, R., 2004. Timing and extent of Plio-Pleistocene glaciations in northwestern Canada and east-central Alaska. In: Ehlers, J., Gibbard, P.L. (Eds.), Quaternary Glaciations-Extent and Chronology, Part II: North America. Elsevier, Amsterdam, pp. 313-345.

Dyke, A.S., Prest, V.K., 1987. Late Wisconsinan and Holocene history of the Laurentide Ice Sheet. Géographie Physique et Quaternaire 41, 237-263.

Dyke, A.S., Andrews, J.T., Clark, P.U., England, J.H., Miller, G.H., Shaw, J., Veillette, J.J., 2002. The Laurentide and Innuitian ice sheets during the Last Glacial Maximum. Quaternary Science Reviews 21, 9-31.

Dyke, A.S., Moore, A., Robertson, L., 2003. Deglaciation of North America. Geological Survey of Canada Open File 1574

Elias, S.A., 2000. Late Pleistocene climates of Beringia, based on analysis of fossil beetles. Quaternary Research 53, 229-235.

Engstrom, D.R., Hansen, B.C.S., Wright Jr., H.E., 1990. A possible Younger Dryas record in southeastern Alaska. Science 250, 1383-1385.

Engstrom, D.R., Fritz, S.C., Almendinger, J.E., Juggins, S., 2000. Chemical and biological trends during lake evolution in recently deglaciated terrain. Nature 408, 161-166.

Environment Canada, 2000. http://climate.weatheroffice.ec.gc.ca//index_e.html (accessed June 2011).

Fægri, K., Iversen, J., 1989. Textbook of Pollen Analysis. The Blackwell Press, New Jersey.

Fallu, M.-A., Pienitz, R., Walker, I.R., Overpeck, J., 2004. AMS 14C dating of tundra lake sediments using chironomid head capsules. Journal of Paleolimnology 31, 11-22.

French, H.M., Harry, D.G., 1992. Pediments and cold-climate conditions, Barn Mountains, unglaciated northern Yukon, Canada. Gegrafiska Annaler, Series A, Physical Geography 74, 145-157.

Fritz, M., Wetterich, S., Schirrmeister, L., Meyer, H., Lantuit, H., Preusser, F., Pollard, W.H., 2012. Eastern Beringia and beyond: Late Wisconsinan and Holocene landscape dynamics along the Yukon Coastal Plain, Canada. Palaeogeography, Palaeoclimatology, Palaeoecology 319-320, 28-45.

Grimm, E.C., 1991. TILIA and TILIAGRAPH Software. Illinois State Museum, Springfield.

Grimm, E.C, 2000 . North American Pollen Database. IGBP PAGES/World Data Centre for Paleoclimatology. NOAA/NGDC Paleoclimatology Program, Boulder, USA. http:// www.ngdc.noaa.gov/paleo/pollen.html (accessed June 2011).

Grootes, P.M., Stuiver, M., 1997. Oxygen 18/16 variability in Greenland snow and ice with 10-3- to 10-5-year time resolution. Journal of Geophysical Research 102, 26455-26470.

Guthrie, R.D., 2001. Origin and causes of the mammoth steppe: a story of cloud cover, woolly mammal tooth pits, buckles, and inside-out Beringia. Quaternary Science Reviews 20, 549-574.

Hill, P.R., Mudie, P.J., Moran, K., Blasco, S.M., 1985. A sea-level curve for the Canadian Beaufort Shelf. Canadian Journal of Earth Sciences 22, 1383-1393.

Hopkins, D.M., 1982. Aspects of the paleogeography of Beringia during the Late Pleistocene. In: Hopkins, D.M., Matthews Jr., J.V., Schweger, Ch.E., Young, S.B. (Eds.), Paleoecology of Beringia. Academic Press, New York, pp. 3-28.

Horita, J., Ueda, A., Mizukami, K., Takaton, I., 1989. Automatic $\delta \mathrm{D}$ and $\delta^{18} \mathrm{O}$ analyses of multi-water samples using $\mathrm{H}_{2}$ - and $\mathrm{CO}_{2}$-water equilibration methods with a common equilibration set-up. Applied Radiation and Isotopes 40, 801-805.

Hu, F.S., Lee, B.Y., Kaufman, D.S., Yoneji, S., Nelson, D.M., Henne, P.D., 2002. Response of tundra ecosystem in southwestern Alaska to Younger-Dryas climatic oscillation. Global Change Biology 8, 1156-1163.

Hu, F.S., Nelson, D.M., Clarke, G.H., Rühland, K.M., Huang, Y., Kaufman, D.S., Smol, J.P., 2006. Abrupt climatic events during the last glacial-interglacial transition in Alaska. Geophysical Research Letters 33, L18708.

Hughes, O., 1972. Surficial geology of northern Yukon Territory and northwestern District of Mackenzie, Northwest Territories, Geological Survey of Canada, Paper 69-36. Map 1319 A.

Hultén, E., 1937. Outline of the History of Arctic and Boreal Biota during the Quaternary Period. Bokförlags Aktiebolaget Thule, Stockholm.

Huntley, B., Prentice, I.C., 1988. July temperatures in Europe from pollen data, 6000 years before present. Science 241, 687-690.

Huybers, P., 2006. Early Pleistocene glacial cycles and the integrated summer insolation forcing. Science 313, 508-511.

IAEA (International Atomic Energy Agency), 2006. Isotope Hydrology Information System. The ISOHIS Database. http://www.iaea.org/water. (accessed June 2011).

Irvine, F., Cwynar, L., Vermaire, J., Rees, A.H., 2012. Midge-inferred temperature reconstructions and vegetation change over the last 15,000 years from Trout Lake, northern Yukon Territory, eastern Beringia. Journal of Paleolimnology 48, 133-146.

Juggins, S., 2003. C2 User Guide. Software for Ecological and Palaeoecological Data Analysis and Visualisation. University of Newcastle, Newcastle upon Tyne, UK.
Kaufman, D.S., Ager, T.A., Anderson, N.J., Anderson, P.M., Andrews, J.T., Bartlein, P.J Brubaker, L.B., Coats, L.L., Cwynar, L.C., Duvall, M.L., Dyke, A.S., Edwards, M.E., Eisner, W.R., Gajewski, K., Geirsdottir, A., Hu, F.S., Jennings, A.E., Kaplan, M.R. Kerwin, M.W., Lozhkin, A.V., MacDonald, G.M., Miller, G.H., Mock, C.J., Oswald, W.W., Otto-Bliesner, B.L., Porinchu, D.F., Rühland, K., Smol, J.P., Steig, E.J., Wolfe, B.B., 2004. Holocene thermal maximum in the western Arctic $\left(0-180^{\circ} \mathrm{W}\right)$. Quaternary Science Reviews 23, 529-560.

Keigwin, L., Donnelly, J.P., Cook, M.S., Driscoll, N.W., Brigham-Grette, J., 2006. Rapid sea-level rise and Holocene climate in the Chukchi Sea. Geology 34, 861-864.

Kokorowski, H.D., Anderson, P.M., Mock, C.J., Lozhkin, A.V., 2008. A re-evaluation and spatial analysis of evidence for a Younger Dryas climatic reversal in Beringia. Quaternary Science Reviews 27, 1710-1722.

Kurek, J., Cwynar, L.C., Vermaire, J.C., 2009. A late Quaternary paleotemperature record from Hanging Lake, northern Yukon Territory, eastern Beringia. Quaternary Research 72, 246-257.

Lacourse, T., Gajewski, K., 2000. Late Quaternary vegetation history of Sulphur Lake, southwest Yukon Territory, Canada. Arctic 63, 27-35.

Laskar, J., Robutel, P., Joutel, F., Gastineau, M., Correia, A.C.M., Levrard, B., 2004. A longterm numerical solution for the insolation quantities of the Earth. Astronomy and Astrophysics 428, 261-285.

Lepš, J., Šmilauer, P., 2003. Multivariate analysis of ecological data using CANOCO. Cambridge University Press, Cambridge.

Mann, D.H., Peteet, D.M., Reanier, R.E., Kunz, M.L., 2002. Responses of an arctic landscape to Lateglacial and early Holocene climatic changes: The importance of moisture. Quaternary Science Reviews 21, 997-1021.

Mason, O.K., Bowers, P.M., Hopkins, D.M., 2001. The early Holocene Milankovitch thermal maximum and humans: Adverse conditions for the Denali complex of eastern Beringia. Quaternary Science Reviews 20, 525-548.

McAndrews, J.H., Berti, A.A., Norris, G., 1973. Key to the Quaternary pollen and spores of the Great Lakes region. The University of Toronto Press, Toronto.

Meyer, H., Schirrmeister, L., Yoshikawa, K., Opel, T., Wetterich, S., Hubberten, H.-W., Brown, J., 2010. Permafrost evidence for severe winter cooling during the Younger Dryas in northern Alaska. Geophysical Research Letters 37, L03501.

Meyers, P.A., 1994. Preservation of elemental and isotopic source identification of sedimentary organic matter. Chemical Geology 114, 289-300.

Mikolajewicz, U., Crowley, T.J., Schiller, A., Voss, R., 1997. Modelling teleconnections between the North Atlantic and North Pacific during the Younger Dryas. Nature 387, 384-387.

Moore, P.D., Webb, J.A., Collinson, M.E., 1991. Pollen Analysis. Blackwell Science, Oxford.

Morlan, R.E., Cinq-Mars, J., 1982. Ancient Beringians: Human occupation in the Late Pleistocene of Alaska and the Yukon Territory. In: Hopkins, D.M., Matthews Jr., J.V., Schweger, Ch.E., Young, S.B. (Eds.), Paleoecology of Beringia. Academic Press, New York, pp. 353-381.

Murton, J.B., Frechen, M., Maddy, D., 2007. Luminescence dating of mid- to Late Wisconsinan aeolian sand as a constraint on the last advance of the Laurentide Ice Sheet across the Tuktoyaktuk Coastlands, western Arctic Canada. Canadian Journal of Earth Sciences 44, 857-869.

Nelson, R.E., Carter, L.D., 1987. Paleoenvironmental analysis of insects and extralimital Populus from an early Holocene site on the Arctic slope of Alaska, U.S.A. Arctic and Alpine Research 19, 230-241.

Norris, K., 1977. Blow River and Davidson Mountains, Yukon Territory-District of Mackenzie. Geological Survey of Canada, Map 1516A.

Pienitz, R., Smol, J.P., Last, W.M., Leavitt, P.R., Cumming, B.F., 2000. Multi-proxy Holocene palaeoclimatic record from a saline lake in the Canadian subarctic. The Holocene 10, 673-686.

Rampton, V.N., 1971. Late Quaternary vegetational and climatic history of the SnagKlutlan area, southwest Yukon Territory, Canada. Geological Society of America Bulletin 82, 959-978.

Rampton, V.N., 1982. Quaternary geology of the Yukon Coastal Plain. Geological Survey of Canada Bulletin 317 (49 pp.)

Reimer, P.J., Baillie, M.G., Bard, E., Bayliss, A., Beck, J.W., Blackwell, P.G., Bronk Ramsey, C., Buck, C.E., Burr, G.S., Edwards, R.L., Friedrich, M., Grootes, P.M., Guilderson, T.P., Hajdas, I., Heaton, T.J., Hogg, A.G., Hughen, K.A., Kaiser, K.F., Kromer, B., McCormac, F.G., Manning, S.W., Reimer, R.W., Richards, D.A., Southon, J.R., Talamo, S., Turney, C.S.M., van der Plicht, J., Weyhenmeyer, C.E., 2009. Intcal09 and marine09 radiocarbon age calibration curves, $0-50,000$ years cal BP. Radiocarbon 51,1111-1150.

Ritchie, J.C., 1984. Past and Present Vegetation of the Far Northwest of Canada. University of Toronto Press, Toronto.

Ritchie, J.C., Cwynar, L.C., Spear, R.W., 1983. Evidence from north-west Canada for an early Holocene Milankovitch thermal maximum. Nature 305, 126-128.

Schell, T.M., Scott, D.B., Rochon, A., Blasco, S., 2008. Late Quaternary paleoceanography and paleo-sea ice conditions in the Mackenzie Trough and Canyon, Beaufort Sea. Canadian Journal of Earth Sciences 45, 1399-1415.

Scott, D.B., Schell, T., St-Onge, G., Rochon, A., Blasco, S., 2009. Foraminiferal assemblage changes over the last 15,000 years on the Mackenzie-Beaufort Sea Slope and Amundsen Gulf, Canada: Implications for past sea ice conditions. Paleoceanography 24, PA2219.

Stuiver, M., Reimer, P.J., 1993. Extended ${ }^{14} \mathrm{C}$ data base and revised CALIB $3.0{ }^{14} \mathrm{C}$ age calibration program. Radiocarbon 35, 215-230.

Szeicz, J.M., MacDonald, G.M., Duk-Rodkin, A., 1995. Late Quaternary vegetation history of the central Mackenzie Mountains, Northwest Territories, Canada. Palaeogeography, Palaeoclimatology, Palaeoecology 113, 351-371.

ter Braak, C.J.F., Šmilauer, P., 2002. CANOCO Reference Manual and CANODRAW for Windows User's Guide: Software for Canonical Community Ordination (Version 4.5). Microcomputer Power, New York. 
Vardy, S.R., Warner, B.G., Aravena, R., 1997. Holocene climate effects on the development of a peatland on the Tuktoyaktuk Peninsula, Northwest Territories. Quaternary Research 47, 90-104.

Vermaire, J.C., Cwynar, L.C., 2010. A revised late-Quaternary vegetation history of the unglaciated southwestern Yukon Territory, Canada, from Antifreeze and Eikland ponds. Canadian Journal of Earth Sciences 47, 75-88.

Viau, A.E., Gajewski, K., Sawada, M.C., Bunbury, J., 2008. Low- and high-frequency climate variability in eastern Beringia during the past 25000 years. Canadian Journal of Earth Sciences 45, 1435-1453.

Wahl, H.E., Fraser, D.B., Harvey, R.C., Maxwell, J.B., 1987. Climate of Yukon. Environment Canada, Atmospheric Environment Service, Climatological Studies 40, 1-323.
Wang, X.-C., Geurts, M.-A., 1991. Late Quaternary pollen records and vegetation history of the southwest Yukon Territory: A review. Géographie Physique et Quaternaire 45, 175-193.

Welsh, S.L., Rigby, J.K., 1971. Botanical and physiographic reconnaissance of northern Yukon. Biological Series 14 (64 pp.).

Whitmore, J., Gajewski, K., Sawada, M., Williams, J.W., Minckley, T., Shuman, B. Bartlein, P.J., Webb III, T., Viau, A.E., Shafer, S., Anderson, P., Brubaker, L.B., 2005 A North American modern pollen database for multi-scale paleoecological and paleoclimatic applications. Quaternary Science Reviews 24, 1828-1848.

Yu, Z., Walker, K.N., Evenson, E.B., Hajdas, I., 2008. Lateglacial and early Holocene climate oscillations in the Matanuska Valley, south-central Alaska. Quaternary Science Reviews 27, 148-161. 